\title{
Enriched asthenosphere melting beneath the nascent North African margin: trace element and Nd isotope evidence in middle-late Triassic alkali basalts from central Sicily (Italy)
}

\author{
Rosolino Cirrincione ${ }^{1} \cdot$ Patrizia Fiannacca $^{1} \cdot$ Michele Lustrino $^{2} \cdot$ Vanessa Romano $^{1} \cdot$ \\ Annunziata Tranchina ${ }^{1}$ Igor M. Villa ${ }^{3,4}$
}

Received: 3 February 2015 / Accepted: 29 April 2015 / Published online: 20 May 2015

(C) Springer-Verlag Berlin Heidelberg 2015

\begin{abstract}
During the dismembering of the Pangea supercontinent, middle-late Triassic sub-volcanic alkaline rocks were emplaced in central Sicily. These rocks have an alkali basaltic composition and show OIB-like incompatible element patterns in primitive mantle-normalized diagrams (e.g., enrichments in HFSE and LREE coupled with high HFSE/LILE ratios), as well as slightly positive $\varepsilon_{\mathrm{Nd}}$ values. Only subtle effects of crustal contamination at shallow depths emerge from geochemical data. These characteristics are very different compared with the Permian calcalkaline magmas from elsewhere in SW Europe still carrying the geochemical signature of modifications related to the Variscan orogeny. The mineralogical, geochemical and isotopic compositions of the investigated samples from central Sicily are also different from the coeval shoshonitic volcano-plutonic formations of Southern Alps (Dolomites). The incompatible element composition and $\mathrm{Nd}$ isotopic ratios are consistent with low-degree partial melting of a moderately depleted asthenospheric mantle source, with a negligible involvement of the thinned continental crust. The studied alkaline basalts represent the only known evidence of a segment of the Triassic rift system associated with
\end{abstract}

Patrizia Fiannacca

pfianna@unict.it

1 Dipartimento di Scienze Biologiche, Geologiche e Ambientali, Università di Catania, Corso Italia, 57, 95129 Catania, Italy

2 CNR - IGAG, c/o Dipartimento di Scienze della Terra, Università degli Studi di Roma La Sapienza, Piazzale Aldo Moro, 00185 Rome, Italy

3 Centro Universitario Datazioni e Archeometria, Università di Milano Bicocca, 20126 Milan, Italy

4 Institut für Geologie, Universität Bern, Baltzerstrasse 3, 3012 Bern, Switzerland early Pangea breakup in central Sicily. The close similarity of the central Sicily Triassic alkali basalts with coeval basalts emplaced along former orogenic sutures across the peri-Mediterranean area suggests a common origin related, at least partly, to asthenospheric passive upwelling following the tectonic collapse of the Variscan Belt. These rocks provide new constraints on the spatial-temporal distribution, magma source evolution and geodynamic meaning of the widespread Permo-Triassic basic magmatism developed after the end of the Variscan Orogeny in southwestern Europe.

Keywords Alkali basalts - Ladinian-Carnian . Petrogenesis · Mantle upwelling · Pangea breakup . Southern Italy

\section{Introduction}

Sodic alkali basalts are typically present in oceanic and continental mid-plate settings, or associated with continental rifting zones. Focusing on the continental plates only, this kind of magmatism represents an essential source of information about the thermal state and the chemical composition of the upper mantle away from subduction settings. The main geochemical characteristics of these magmas are the enrichment in high-field-strength elements (HFSE) and associated high HFSE/LILE (large ion lithophile elements) ratios. The main petrogenetic processes proposed to account for these compositions are far from being completely understood, and a number of solutions have been suggested, ranging from a provenance from the lithospheric mantle (e.g., Pilet 2015), the shallow sublithospheric mantle (e.g., Doglioni et al. 2003; Anderson 2013), the transition zone mantle (e.g., Lustrino and Wilson 
2007) or the base of the deep mantle (the $D^{\prime \prime}$ seismic zone; e.g., Kamber and Collerson 1999; Collerson et al. 2010; Li et al. 2014). It clearly emerges that the entire mantle has been alternatively invoked as a potential source, depending on the thermal, chemical, mineralogical, rheological and thermodynamic assumptions adopted in each case. The identification of the type of enriched mantle component involved in the magma production is indeed one of the main problems in understanding the origin of continental magmatism together with the recognition of the typology of the tectonic mechanism triggering the partial melting of the magmatic source.

The above classes of petrogenetic models proposed to explain the igneous activity away from active spreading ridges and collisional settings can be grouped into two major categories: (a) presence of a thermal anomaly in the form of a solid mantle diapir upwelling adiabatically from the core-mantle boundary layer, usually referred to a mantle plume (e.g., Wilson and Patterson 2001; Courtillot et al. 2003) and (b) presence of chemical anomalies as represented by the presence of low-solidus lithologies dispersed in the shallow mantle (e.g., Anderson 2011; Lustrino and Anderson 2015). In the first case, the forces responsible for continent breakup are related to the presence of anomalously hot mantle upwelling, producing active tectonic rifting and intraplate magmatism, commonly preceded by an upcoming stage caused by buoyant mantle. In the second case, the igneous activity is related to differential stress in the shallow sub-lithospheric mantle, considered to be very close to its solidus temperature. Alternatively, partial melts can be already present in the shallow sub-lithospheric mantle as melt lamellae in a harzburgitic-lherzolitic matrix. These stagnating melts are likely derived from olivine-poor lithotypes characterized by low solidus temperature compared with volatile-free peridotite (Cordery et al. 1997; Lustrino and Anderson 2015). Lithospheric thinning can trigger upwelling of the lithosphere-asthenosphere mechanical boundary (represented by the abrupt decrease of $V_{\mathrm{s}}$ ), inducing adiabatic decompression evolving to largescale partial melting (e.g., Lustrino and Sharkov 2006; Lucassen et al. 2008).

The continental rifting related to the early stages of Pangea breakup is widely documented throughout the European continent (e.g., Beccaluva et al. 2005; Bortolotti and Principi 2005; Martin-Rojas et al. 2009; Handy et al. 2010). Numerous occurrences of alkaline magmatic products are related to this continental-scale process, such as the late Permian mildly alkaline basalts and dolerites of the southern Pyrenees (Lago et al. 2004), the Late Permian alkaline lamprophyres and alkali basalts of the Spanish Central System (e.g., Villaseca et al. 2004; Orejana et al. 2008), the Late Permian-middle Triassic basanites, alkali basalts, hawaiites and mugearites of the Sardinia-Corsica Domain (SCD; Traversa et al. 2003), the Middle Triassic basaltic dykes in the northern Calabria-Peloritani Orogen (e.g., Barca et al. 2010), the Middle-Late Triassic basalts to trachytes of the Southern Alps (e.g., Armienti et al. 2003; Bellieni et al. 2010), the Middle-Late Triassic alkali basalts of the Hellenide orogenic Belt (e.g., Pe-Piper 1998; Pe-Piper and Piper 2002; Bortolotti et al. 2008) and the Late Triassic alkali basalts of Spain (e.g., Sanz et al. 2013), Oman (Chauvet et al. 2011), Cyprus (Lapierre et al. 2007), Turkey
Fig. 1 General tectonic framework of Sicily (modified after Tortorici et al. 2001) with location of the study area (star). Inset shows the central Mediterranean area with the frontal thrust of the Maghrebian orogenic belt. 1 Quaternary deposits, 2 Neogene-Early Pleistocene deposits of the Maghrebian chain s.s, 3 KabiloCalabride domain (internal sector), 4 Numidian Flysch unit (Lower Miocene; Maghrebian chain s.s), 5 Meso-Cenozoic carbonate platform (Panormide and Trapanese) and slope to deep water basin (Imerese and Sicanian) units of the Maghrebian chain s.s., 6 MesoCenozoic carbonate foreland succession (Hyblean Plateau), 7 main thrusts

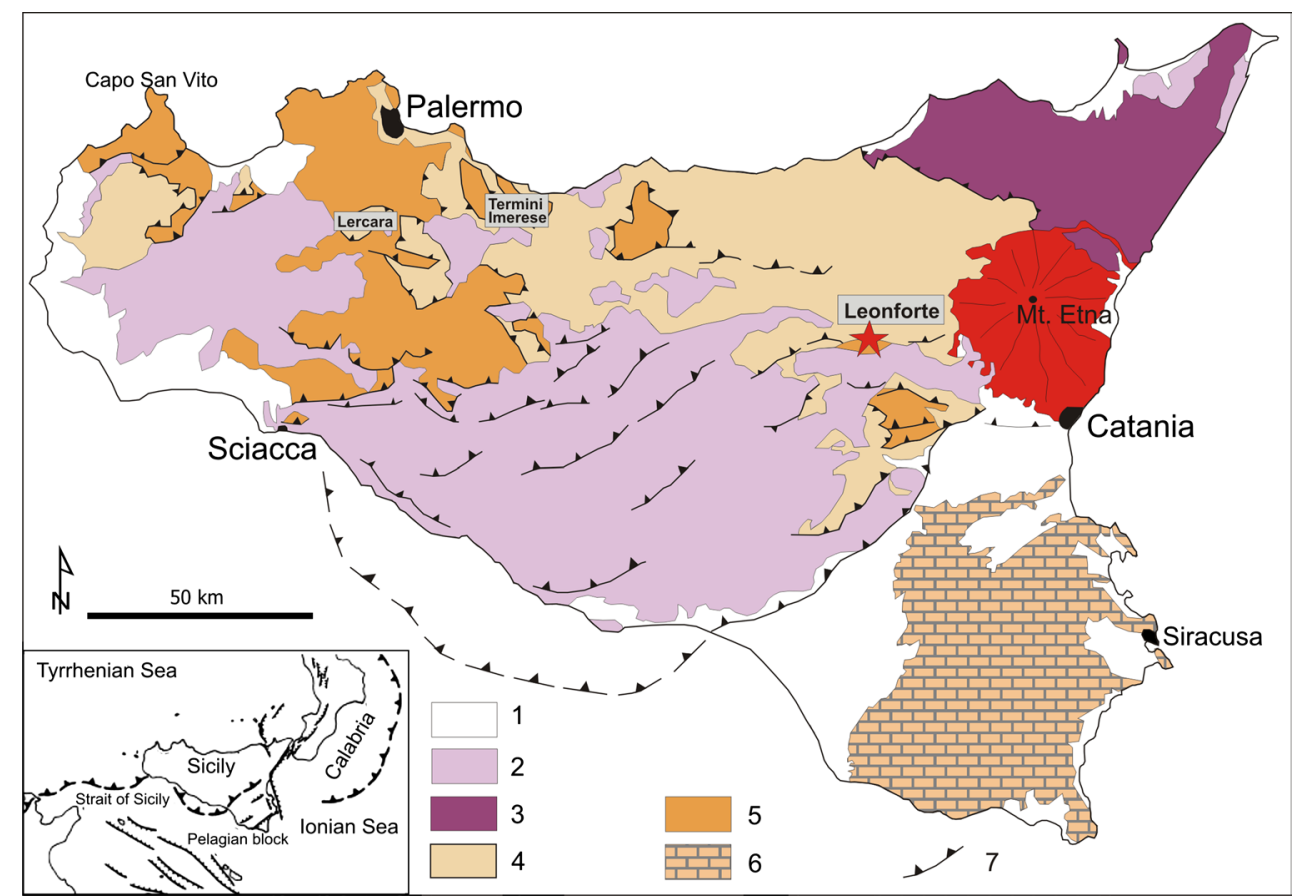


Fig. 2 a Geological sketch map of Mt. Altesina area (modified after Grasso and Scribano 1985). 1 Micritic limestones, black shales, cherty siltites and tuffites with syn-sedimentary basaltic sill (Middle-Late Triassic), 2 variegated clays (Cretaceous-Eocene), 3 Numidian Flysch (Late Oligocene-Early Miocene): brown clays (a) and quartz arenites (b), 4 clays with sandy intercalations (Tortonian), 5 "Calcare di base," gypsum, clays (Messinian) and marls (early Pliocene), 6 marly clays grading up to calcarenites (Middle-Late Pliocene), 7 recent alluvial sediments; $\mathbf{b}$ schematic cross section of the studied sill on the southern slope of Mt. Altesina (N $37^{\circ} 38^{\prime} 25^{\prime \prime}$, E $14^{\circ} 19^{\prime} 40^{\prime \prime}$; modified after Grasso and Scribano 1985)

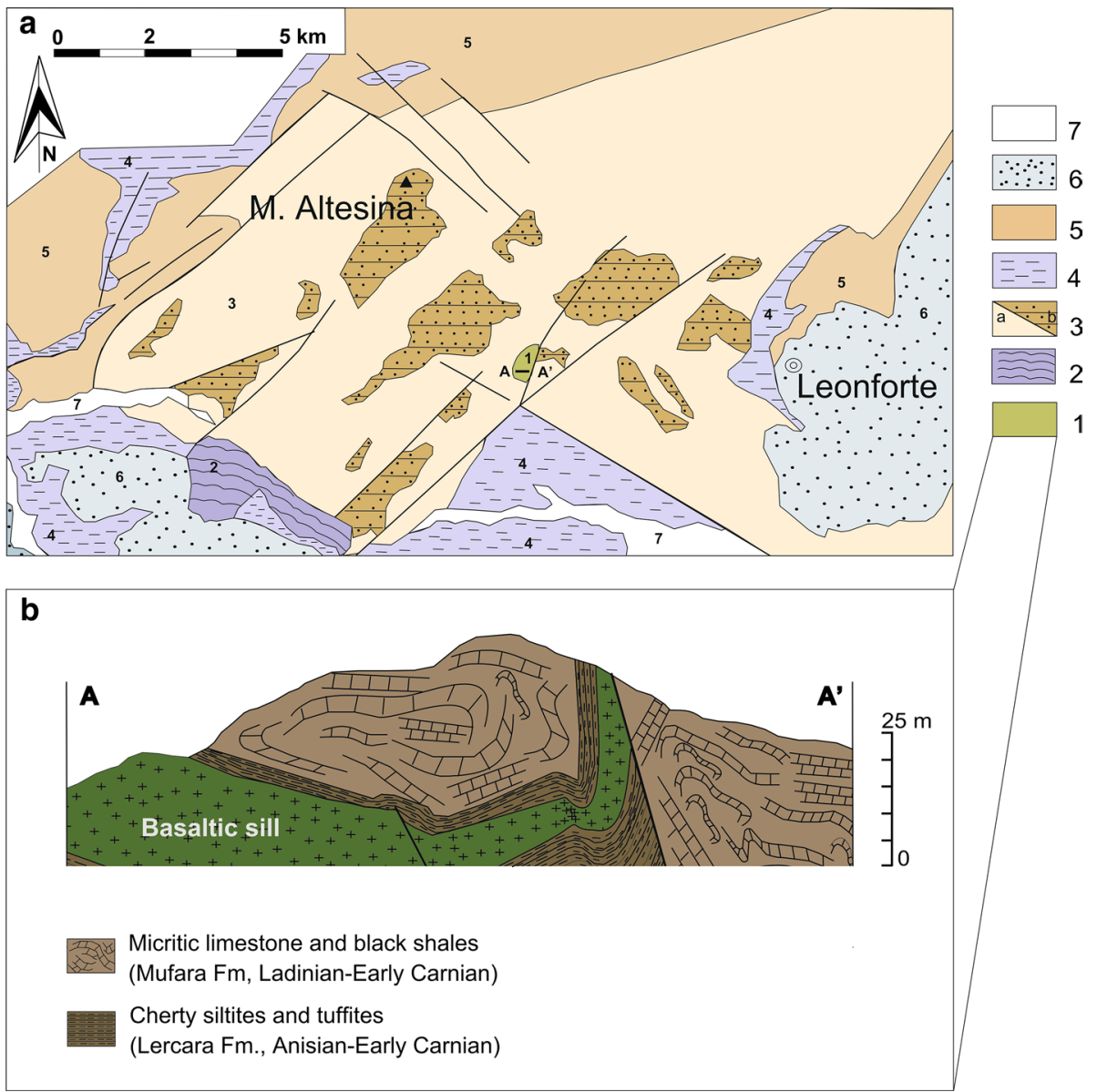

(Antalya Nappe; Maury et al. 2008) and Syria (Al-Riyami and Robertson 2002).

Middle-Late Triassic magmatism related to the continental rifting processes is also documented in western-central Sicily (Bellia et al. 1982; Grasso and Scribano 1985; Grasso et al. 1995; Guarnieri et al. 2000), but up to now little has been inferred about the geodynamic significance in the Mesozoic Mediterranean geodynamic framework. A possible kinship between Late Triassic basaltic rocks from Western Sicily and the tholeiitic basalts of the Central Atlantic Magmatic Province (Marzoli et al. 1999, 2011) has been recently envisaged by Cirrincione et al. (2014), based on geochemical and isotopic data. On the contrary, detailed petrological information is still totally lacking for the middle-late Triassic magmatic products of central Sicily.

In this framework, our study aims to provide petrological constraints on mantle sources and mechanisms involved in alkaline magma production in the nascent southern Tethyan paleo-margin through the investigation of one of the rare Triassic basalt occurrences known in central Sicily. Furthermore, we highlight that these rocks may play an important role in the reconstruction of the spatial-temporal distribution, magma source evolution and related geodynamic implications of the widespread Permo-Triassic basic magmatism developed after the end of the Variscan Orogeny in southwestern Europe.

\section{Geological background and outcrop description}

The simplified geological framework of Sicily (Fig. 1) is characterized by the presence of two main geological domains, inherited by the Cenozoic convergence and collision between the European and Africa-Adria plates: the Hyblean Plateau, part of the African foreland, and an orogenic belt (Maghrebian Chain) representing the Sicilian sector of the Apennine-Maghrebian Orogen (Grasso 2001; Cella et al. 2004; Carminati et al. 2012). The Hyblean Plateau, located in the southeastern part of the island, is composed of carbonate successions interbedded with volcanics ranging in age from Late Triassic to Pleistocene (e.g., Longaretti and Rocchi 1990; Punturo and Scribano 1997; Avanzinelli et al. 2012; Punturo et al. 2013).

The Maghrebian Chain consists of a thin-skinned southverging fold-and-thrust belt, an originally $\mathrm{NE}-\mathrm{SW}$-oriented orogen developed as a consequence of the Late Eocene to 
Table 1 Representative compositions of clinopyroxene from the Leonforte sill

\begin{tabular}{|c|c|c|c|c|c|c|c|c|c|c|c|c|c|c|c|c|}
\hline & \multicolumn{5}{|l|}{$\mathrm{VG} 1^{\mathrm{a}}$} & \multicolumn{5}{|l|}{$\mathrm{VG}^{\mathrm{a}}$} & \multicolumn{6}{|l|}{ VG11 ${ }^{\mathrm{b}}$} \\
\hline & $\mathrm{Ph} 1 \mathrm{c}$ & Ph1 r & $\mathrm{Ph} 2 \mathrm{c}$ & $\mathrm{Ph} 2 \mathrm{r}$ & $\mathrm{Ph} 3 \mathrm{r}$ & Ph1 r & Ph1 c & Ph1 r & $\mathrm{Ph} 2 \mathrm{c}$ & $\mathrm{Ph} 2 \mathrm{r}$ & Ph1 r & Ph1 c & Ph1 r & $\mathrm{Ph} 2 \mathrm{r}$ & $\mathrm{Ph} 2 \mathrm{c}$ & $\mathrm{Ph} 2 \mathrm{r}$ \\
\hline $\mathrm{SiO}_{2}$ & 51.46 & 50.98 & 52.87 & 53.54 & 51.30 & 51.55 & 51.91 & 50.18 & 54.37 & 53.15 & 51.09 & 47.62 & 49.98 & 50.26 & 48.26 & 49.49 \\
\hline $\mathrm{TiO}_{2}$ & 1.41 & 1.58 & 1.37 & 0.88 & 2.12 & 1.67 & 1.47 & 2.23 & 0.94 & 1.29 & 1.26 & 2.22 & 1.01 & 0.88 & 1.86 & 1.62 \\
\hline $\mathrm{A}_{2}{ }_{2} \mathrm{O}_{3}$ & 5.85 & 6.03 & 2.70 & 2.92 & 6.37 & 4.14 & 4.16 & 5.54 & 2.43 & 3.99 & 2.67 & 5.04 & 2.14 & 1.93 & 3.86 & 3.87 \\
\hline $\mathrm{FeO}^{\mathrm{c}}$ & 5.24 & 6.10 & 8.72 & 5.73 & 7.34 & 7.85 & 7.01 & 8.00 & 6.88 & 6.92 & 8.07 & 8.60 & 11.57 & 11.69 & 9.57 & 7.80 \\
\hline $\mathrm{Cr}_{2} \mathrm{O}_{3}$ & 0.73 & 0.60 & 0.13 & 0.61 & 0.10 & bdl & bdl & bdl & bdl & bdl & bdl & bdl & bdl & bdl & bdl & bdl \\
\hline $\mathrm{MnO}$ & 0.00 & 0.00 & 0.00 & 0.00 & 0.00 & bdl & bdl & bdl & bdl & bdl & 0.15 & 0.18 & 0.29 & 0.44 & 0.22 & 0.11 \\
\hline $\mathrm{MgO}$ & 16.27 & 15.89 & 14.36 & 16.60 & 14.02 & 14.34 & 14.89 & 13.90 & 17.18 & 15.31 & 15.19 & 13.68 & 12.46 & 12.84 & 13.53 & 14.50 \\
\hline $\mathrm{CaO}$ & 17.82 & 18.20 & 19.23 & 19.12 & 17.19 & 19.94 & 20.02 & 19.73 & 18.21 & 19.33 & 21.85 & 21.42 & 21.78 & 21.57 & 21.70 & 21.94 \\
\hline $\mathrm{Na}_{2} \mathrm{O}$ & 1.22 & 0.62 & 0.61 & 0.60 & 1.57 & 0.51 & 0.53 & 0.42 & 0.00 & 0.00 & 0.31 & 0.40 & 0.34 & 0.39 & 0.39 & 0.35 \\
\hline Total & 100.00 & 100.00 & 99.99 & 100.00 & 100.01 & 100.00 & 99.99 & 100.00 & 100.01 & 99.99 & 100.59 & 99.16 & 99.57 & 100.00 & 99.39 & 99.68 \\
\hline $\mathrm{Mg \#}$ & 84.71 & 82.26 & 74.58 & 83.80 & 77.32 & 76.52 & 79.13 & 75.61 & 81.61 & 79.77 & 77.06 & 73.91 & 65.73 & 66.24 & 71.62 & 76.84 \\
\hline $\mathrm{Si}$ & 1.87 & 1.87 & 1.96 & 1.96 & 1.88 & 1.91 & 1.92 & 1.86 & 2.00 & 1.97 & 1.88 & 1.79 & 1.89 & 1.89 & 1.81 & 1.84 \\
\hline $\mathrm{Al}^{\mathrm{IV}}$ & 0.13 & 0.13 & 0.04 & 0.04 & 0.12 & 0.09 & 0.09 & 0.14 & 0.00 & 0.03 & 0.12 & 0.22 & 0.10 & 0.09 & 0.17 & 0.16 \\
\hline $\operatorname{Sum} T$ & 2.00 & 2.00 & 2.00 & 2.00 & 2.00 & 2.00 & 2.00 & 2.00 & 2.00 & 2.00 & 2.00 & 2.00 & 1.99 & 1.98 & 1.98 & 2.00 \\
\hline $\mathrm{Al}^{\mathrm{VI}}$ & 0.12 & 0.13 & 0.08 & 0.09 & 0.16 & 0.09 & 0.10 & 0.11 & 0.10 & 0.14 & 0.00 & 0.01 & 0.00 & 0.00 & 0.00 & 0.01 \\
\hline $\mathrm{Ti}$ & 0.04 & 0.04 & 0.04 & 0.02 & 0.06 & 0.05 & 0.04 & 0.06 & 0.03 & 0.04 & 0.04 & 0.06 & 0.03 & 0.03 & 0.05 & 0.05 \\
\hline $\mathrm{Fe}^{3+}$ & 0.00 & 0.00 & 0.00 & 0.00 & 0.00 & 0.00 & 0.00 & 0.00 & 0.00 & 0.00 & 0.00 & 0.00 & 0.00 & 0.00 & 0.00 & 0.00 \\
\hline $\mathrm{Fe}^{2+}$ & 0.16 & 0.19 & 0.27 & 0.18 & 0.23 & 0.24 & 0.22 & 0.25 & 0.21 & 0.21 & 0.25 & 0.27 & 0.37 & 0.37 & 0.30 & 0.24 \\
\hline $\mathrm{Cr}$ & 0.02 & 0.02 & 0.00 & 0.02 & 0.00 & 0.00 & 0.00 & 0.00 & 0.00 & 0.00 & 0.00 & 0.00 & 0.00 & 0.00 & 0.00 & 0.00 \\
\hline $\mathrm{Mg}$ & 0.88 & 0.87 & 0.80 & 0.90 & 0.77 & 0.79 & 0.82 & 0.77 & 0.94 & 0.84 & 0.83 & 0.77 & 0.70 & 0.72 & 0.76 & 0.80 \\
\hline $\mathrm{Mn}$ & 0.00 & 0.00 & 0.00 & 0.00 & 0.00 & 0.00 & 0.00 & 0.00 & 0.00 & 0.00 & 0.01 & 0.01 & 0.01 & 0.01 & 0.01 & 0.00 \\
\hline $\mathrm{Ca}$ & 0.69 & 0.71 & 0.77 & 0.75 & 0.68 & 0.79 & 0.79 & 0.79 & 0.72 & 0.77 & 0.86 & 0.86 & 0.88 & 0.87 & 0.87 & 0.87 \\
\hline $\mathrm{Na}$ & 0.09 & 0.04 & 0.04 & 0.04 & 0.11 & 0.04 & 0.04 & 0.03 & 0.00 & 0.00 & 0.02 & 0.03 & 0.03 & 0.03 & 0.03 & 0.03 \\
\hline Cations & 4.00 & 4.00 & 4.00 & 4.00 & 4.01 & 4.00 & 4.00 & 4.00 & 4.00 & 4.00 & 4.00 & 4.00 & 4.00 & 4.00 & 4.00 & 4.00 \\
\hline Wo & 40.00 & 40.38 & 41.79 & 40.95 & 40.52 & 43.33 & 43.32 & 43.54 & 38.35 & 41.99 & 44.23 & 45.28 & 45.02 & 44.10 & 45.05 & 45.43 \\
\hline En & 50.82 & 49.06 & 43.42 & 49.47 & 45.98 & 43.36 & 44.84 & 42.68 & 50.34 & 46.28 & 42.78 & 40.23 & 35.84 & 36.53 & 39.08 & 41.78 \\
\hline $\mathrm{Fe}$ & 9.18 & 10.56 & 14.79 & 9.58 & 13.50 & 13.31 & 11.84 & 13.78 & 11.31 & 11.73 & 12.99 & 14.49 & 19.14 & 19.37 & 15.87 & 12.79 \\
\hline
\end{tabular}

Pyroxene formula unit normalized to six oxygens and recalculated to four cations

$\mathrm{Fe}^{2+/ 3+}$ partitioning according to Papike et al. (1974). The cations are allocated to their structural sites according to IMA guidelines

$\mathrm{Mg} \#=100 \mathrm{Mg} /\left(\mathrm{Mg}+\mathrm{Fe}^{2+}\right)$

$b d l$ below detection limit, $P h$ phenocryst, $r$ rim, $c$ core

${ }^{a}$ SEM analyses

b Electron microprobe analyses

c Total $\mathrm{Fe}$ as $\mathrm{FeO}$

Present NW-directed subduction of oceanic lithosphere (Tortorici et al. 2001; Carminati et al. 2012, and references therein). This chain is made up of three complexes: (a) an internal sector (the Kabilo-Calabride domain), in northeastern Sicily, representing a pre-Mesozoic crystalline basement belonging to the European continental margin (Calabria-Peloritani Orogen; Cirrincione et al. 2005, 2009, 2012; Appel et al. 2011; Fiannacca et al. 2013); (b) the Maghrebian Chain s.s., consisting of Meso-Cenozoic pelagic deposits and turbiditic successions (Lentini et al. 1994; Grasso 2001; Tortorici et al. 2001; Maniscalco et al. 2010); and (c) the external thrust system formed by neritic to pelagic carbonate units from the northern African paleomargin (Lentini et al. 1994; Cirrincione 1996; Tortorici et al. 2001).

The study area is located in central Sicily, within a zone affected by the presence of a large structural depression (Caltanissetta basin) playing a role of a foredeep basin until the Tortonian (Fig. 1). We investigated a sub-volcanic basaltic body cropping out near Leonforte village, along the southern slope of Mt. Altesina (N $37^{\circ} 38^{\prime} 25^{\prime \prime}$, E $14^{\circ} 19^{\prime} 40^{\prime \prime}$; Fig. 2a). The sub-volcanic body consists of a sill of a thickness up to $25 \mathrm{~m}$; the color is gray and the microstructure holocrystalline, from fine- to 
medium-grained portions moving toward the thickest parts of the body.

The sill intruded into the uppermost levels of a well-bedded pelagic sequence of cherty siltites and tuffites attributed to the Anisian-Early Carnian Lercara Formation (Grasso and Scribano 1985; Grasso et al. 1995; Carrillat and Martini 2009; Fig. 2b), cropping out more extensively in western Sicily. This formation is here covered by a 10-m-thick succession of black shales and micritic limestones of the Mufara Formation, dated as Late Ladinian-Early Carnian (Carrillat and Martini 2009); the contact between the Mufara and Lercara Formations is marked by evidence of syn-sedimentary disturbance, such as local unconformities, local sliding and truncated beds, all likely caused by the intrusion of the sill into still poorly consolidated host rocks. The intrusion is therefore postdating the youngest sediments of Lercara Formation as well as the oldest ones of the Mufara formation, but predating the younger undisturbed sediments of the latter formation. As a consequence, a Late Ladinian-Early Carnian age ( 240-230 Ma) has been assigned to this intrusion (Grasso and Scribano 1985).

\section{Analytical methods}

Mineral compositions (Table 1) were obtained using Cameca SX50 electron microprobe at the Istituto di Geologia Ambientale e Geoingegneria (IGAG) - CNR, Rome, with silicates and oxides as standards, and by SEM-EDS analyses at the Department of Biological, Geological and Environmental Sciences, University of Catania, using a Tescan Vega LMU scanning electron microscope equipped with an EDAX Neptune XM4-60 micro-analyzer characterized by an ultrathin Be window. Analyses were performed at $20 \mathrm{kV}$ accelerating voltage and $0.2 \mathrm{nA}$ beam current. Precision of collected data is typically better than $5 \%$.

Whole-rock major and trace element contents of eleven samples (Table 2) were determined by X-ray fluorescence (XRF) on pressed powder pellets, corrected for matrix effects (Franzini et al. 1975), at the Department of Biological, Geological and Environmental Sciences, University of Catania. XRF analyses were carried out on a Philips PW 2404 spectrometer, equipped with Rh anticathode. Uncertainties are $\sim 1 \%$ for major oxides and $\sim 5 \%$ for element concentrations $<1.0 \mathrm{wt} \%$. Volatile content was measured as weight loss on ignition (LOI) by standard gravimetric method. ICP-MS analyses for trace element concentrations were obtained at SGS Mineral Services (Toronto, Canada). Precision and accuracy are better than $10 \%$ for all the elements.

$\mathrm{Rb}, \mathrm{Sr}, \mathrm{Sm}$ and $\mathrm{Nd}$ isotopic compositions were measured on two representative sill samples. Sample powders
( $\sim 0.1 \mathrm{~g}$ ) were spiked with a ${ }^{87} \mathrm{Rb}-{ }^{84} \mathrm{Sr}-{ }^{149} \mathrm{Sm}-{ }^{150} \mathrm{Nd}$ tracer and dissolved in screw-top PTFE vials with a $\mathrm{HF}-\mathrm{HNO}_{3}$ mixture. $\mathrm{Rb}, \mathrm{Sr}$ and REE were separated from matrix elements using AG50WX8 cation exchange resin in $\mathrm{HCl}$ medium. $\mathrm{Nd}$ and $\mathrm{Sm}$ were separated from the other REE using HDHP cation exchange resin in $\mathrm{HCl}$ medium. Isotopic compositions were determined on a $\mathrm{Nu}$ Instruments ${ }^{\mathrm{TM}}$ multicollector inductively coupled plasma mass spectrometer at the University of Bern (Buettner et al. 2005). Rb mass fractionation was corrected by doping with common Sr (Villa et al. 2006). Sr mass fractionation was corrected by normalizing to ${ }^{86} \mathrm{Sr} /{ }^{88} \mathrm{Sr}=0.1194$. Repeated measurements $(n=5)$ of NIST SRM 987 bracketing the Leonforte samples gave ${ }^{87} \mathrm{Sr} /{ }^{86} \mathrm{Sr}=0.710212$ with a $2 \sigma$ external reproducibility of \pm 0.000024 . Sm mass fractionation was corrected by normalizing to ${ }^{147} \mathrm{Sm} /{ }^{152} \mathrm{Sm}=0.560828$. $\mathrm{Nd}$ mass fractionation was corrected by normalizing to ${ }^{146} \mathrm{Nd} /{ }^{144} \mathrm{Nd}=0.7219$. Repeated bracketing measurements $(n=4)$ of an in-house $\mathrm{Nd}$ standard yielded ${ }^{143} \mathrm{Nd} /{ }^{144} \mathrm{Nd}=0.511044$, corresponding to La Jolla ${ }^{143} \mathrm{Nd} /{ }^{144} \mathrm{Nd}=0.511844$ with a $2 \sigma$ external reproducibility of \pm 0.000013 . Model ages $t_{\mathrm{DM}}(\mathrm{Nd})$ were calculated following Nägler and Kramers (1998). Results are shown in Table 3 .

\section{Petrography and mineral chemistry}

The Leonforte sub-volcanic body is characterized by a porphyritic to equigranular texture with a fine- to mediumgrained matrix and a common ophitic microstructure, characterized by plagioclase laths embedded in zoned clinopyroxene crystals. Clinopyroxene, usually observed as phenocrysts, is intensively fractured but unaltered and often concentrically or sector (hour-glass) zoned. Its composition ranges from diopside to augite $\left(\mathrm{Wo}_{368-46} \mathrm{En}_{368-518} \mathrm{Fs}_{7-17}\right.$; Table 1; Fig. 3), with variable contents of $\mathrm{CaO}$ (16.4$22.2 \mathrm{wt} \%), \mathrm{Al}_{2} \mathrm{O}_{3}$ (1.9-6.5 wt $\left.\%\right), \mathrm{Na}_{2} \mathrm{O}(0.3-1.6 \mathrm{wt} \%)$ and $\mathrm{TiO}_{2}(0.7-2.2 \mathrm{wt} \%)$. Rarely and only in some Mg-rich crystals, small amounts of $\mathrm{Cr}$ have been detected (average $\mathrm{Cr}_{2} \mathrm{O}_{3}=0.50 \mathrm{wt} \%$ ). Both $\mathrm{MgO}$ and $\mathrm{FeO}$ show large variation (from 12.5 to 18.8 and from 3.9 to $11.7 \mathrm{wt} \%$, respectively), resulting in a large $\mathrm{Mg \#}$ range (66-85). Compositional zoning, clearly observable in thin section, reflects an increase in $\mathrm{FeO}, \mathrm{TiO}_{2}$ and $\mathrm{Al}_{2} \mathrm{O}_{3}$ content, coupled with $\mathrm{MgO}$ decrease from core to rim. In the $(\mathrm{Ti}+\mathrm{Cr})$ versus $\mathrm{Ca}$ diagram (Leterrier et al. 1982; Fig. 3), clinopyroxene compositions fall in the non-orogenic basalts field.

Plagioclase is euhedral, albitized and sericitized, without magmatic zoning and showing only rare twinning. Small amounts of interstitial biotite occur, but several attempts of determining its composition did not provide reliable results on the original magmatic mineral due to pervasive 
Table 2 Major (wt\%) and trace (ppm) element concentrations of Leonforte alkali basalts

\begin{tabular}{|c|c|c|c|c|c|c|c|c|c|c|c|}
\hline & $\begin{array}{l}\text { VG1 } \\
\text { (1) }\end{array}$ & $\begin{array}{l}\text { VG2 } \\
\text { (1) }\end{array}$ & $\begin{array}{l}\text { VG3 } \\
\text { (1) }\end{array}$ & $\begin{array}{l}\text { VG4 } \\
\text { (1) }\end{array}$ & $\begin{array}{l}\text { VG5 } \\
\text { (1) }\end{array}$ & $\begin{array}{l}\text { VG6 } \\
\text { (1) }\end{array}$ & $\begin{array}{l}\text { VG7 } \\
\text { (1) }\end{array}$ & $\begin{array}{l}\text { VG8 } \\
\text { (1) }\end{array}$ & $\begin{array}{l}\text { VG9 } \\
\text { (1) }\end{array}$ & $\begin{array}{l}\text { VG10 } \\
\text { (1) }\end{array}$ & $\begin{array}{l}\text { VG11 } \\
\text { (1) }\end{array}$ \\
\hline $\mathrm{SiO}_{2}$ & 45.35 & 46.20 & 46.76 & 44.61 & 46.41 & 42.56 & 48.35 & 49.32 & 47.91 & 47.67 & 47.22 \\
\hline $\mathrm{TiO}_{2}$ & 2.42 & 2.62 & 2.17 & 2.16 & 2.57 & 2.21 & 2.23 & 2.19 & 2.37 & 2.12 & 2.34 \\
\hline $\mathrm{Al}_{2} \mathrm{O}_{3}$ & 12.23 & 12.42 & 13.15 & 13.58 & 13.03 & 12.28 & 13.80 & 15.00 & 13.97 & 14.30 & 13.77 \\
\hline $\mathrm{Fe}_{2} \mathrm{O}_{3 \mathrm{t}}$ & 13.45 & 13.87 & 12.97 & 11.30 & 13.82 & 11.47 & 12.61 & 11.36 & 13.10 & 12.38 & 12.77 \\
\hline $\mathrm{MgO}$ & 10.14 & 9.25 & 8.32 & 7.54 & 8.19 & 6.30 & 6.79 & 5.41 & 6.49 & 5.87 & 5.61 \\
\hline $\mathrm{CaO}$ & 7.35 & 6.54 & 10.56 & 11.07 & 6.75 & 12.60 & 6.94 & 8.16 & 7.66 & 8.79 & 8.38 \\
\hline $\mathrm{Na}_{2} \mathrm{O}$ & 3.02 & 3.46 & 3.50 & 3.45 & 3.67 & 3.65 & 4.27 & 4.04 & 3.98 & 3.87 & 4.14 \\
\hline $\mathrm{K}_{2} \mathrm{O}$ & 0.38 & 0.19 & 0.58 & 0.06 & 0.27 & 0.05 & 0.41 & 0.63 & 0.48 & 0.56 & 0.70 \\
\hline $\mathrm{P}_{2} \mathrm{O}_{5}$ & 0.38 & 0.38 & 0.38 & 0.37 & 0.38 & 0.34 & 0.40 & 0.39 & 0.43 & 0.41 & 0.42 \\
\hline $\mathrm{MnO}$ & 0.17 & 0.18 & 0.14 & 0.14 & 0.18 & 0.13 & 0.16 & 0.15 & 0.16 & 0.15 & 0.15 \\
\hline LOI & 5.12 & 4.88 & 1.47 & 5.72 & 4.73 & 8.42 & 4.05 & 3.35 & 3.45 & 3.89 & 4.48 \\
\hline $\mathrm{Mg \#}$ & 59.9 & 56.9 & 55.9 & 56.9 & 54.0 & 52.1 & 51.6 & 48.5 & 49.5 & 48.5 & 46.5 \\
\hline $\mathrm{Rb}$ & 12.4 & 4.5 & 10.7 & 1.0 & 6.3 & 2.4 & 8.0 & 12.9 & 11.1 & 15.8 & 14.4 \\
\hline $\mathrm{Ba}$ & 110 & 51 & 250 & 54 & 593 & 434 & 133 & 169 & 290 & 290 & 209 \\
\hline $\mathrm{Sr}$ & 517 & 229 & 537 & 222 & 404 & 466 & 450 & 560 & 439 & 421 & 584 \\
\hline $\mathrm{Pb}$ & 4.6 & 9.3 & 4.7 & 5.3 & 7.6 & 4.5 & 4.4 & 3.8 & 3.3 & 4.0 & 7.6 \\
\hline $\mathrm{Zr}$ & 132 & 145 & 142 & 129 & 147 & 160 & 148 & 148 & 146 & 148 & 158 \\
\hline Y & 19.9 & 22.4 & 20.9 & 19.7 & 21.4 & 21.9 & 22.7 & 21.1 & 21.8 & 21.0 & 22.6 \\
\hline $\mathrm{Nb}$ & 27.7 & 32.3 & 29.9 & 28.6 & 32.0 & 31.3 & 31.7 & 31.7 & 31.9 & 31.2 & 33.1 \\
\hline $\mathrm{Cr}$ & 200 & 192 & 199 & 162 & 200 & 175 & 67 & 103 & 88 & 52 & 54 \\
\hline $\mathrm{Ni}$ & 136 & 94 & 84 & 78 & 80 & 64 & 54 & 61 & 60 & 56 & 48 \\
\hline Co & 77 & 80 & 70 & 62 & 71 & 61 & 65 & 62 & 65 & 63 & 65 \\
\hline V & 118 & 136 & 121 & 123 & 133 & 110 & 118 & 112 & 116 & 108 & 121 \\
\hline \multirow[t]{2}{*}{$\mathrm{Zn}$} & 76 & 71 & 76 & 57 & 72 & 65 & 74 & 71 & 72 & 76 & 79 \\
\hline & (2) & & (2) & & & (2) & (2) & & & & (2) \\
\hline Cs & 0.50 & & 0.60 & & & 0.70 & 0.50 & & & & 0.60 \\
\hline Th & 2.6 & & 2.6 & & & 3.1 & 2.8 & & & & 3.1 \\
\hline $\mathrm{U}$ & 0.76 & & 0.83 & & & 0.98 & 0.83 & & & & 0.91 \\
\hline $\mathrm{Hf}$ & 4.0 & & 4.0 & & & 5.0 & 4.0 & & & & 5.0 \\
\hline $\mathrm{Ta}$ & 2.0 & & 2.1 & & & 2.3 & 2.1 & & & & 2.4 \\
\hline $\mathrm{Sc}$ & 22 & & 23 & & & 22 & 21 & & & & 22 \\
\hline $\mathrm{Ga}$ & 24 & & 26 & & & 27 & 27 & & & & 25 \\
\hline $\mathrm{Cu}$ & 58 & & 80 & & & 80 & 81 & & & & 82 \\
\hline $\mathrm{La}$ & 20.0 & & 20.8 & & & 24.9 & 23.2 & & & & 23.3 \\
\hline $\mathrm{Ce}$ & 42.4 & & 42.6 & & & 50.4 & 47.0 & & & & 48.6 \\
\hline $\operatorname{Pr}$ & 5.39 & & 5.46 & & & 6.26 & 6.14 & & & & 6.29 \\
\hline $\mathrm{Nd}$ & 23.1 & & 22.7 & & & 26.0 & 25.7 & & & & 25.6 \\
\hline $\mathrm{Sm}$ & 5.30 & & 5.40 & & & 5.90 & 5.80 & & & & 6.10 \\
\hline $\mathrm{Eu}$ & 1.86 & & 1.90 & & & 2.00 & 2.12 & & & & 2.05 \\
\hline Gd & 5.11 & & 5.30 & & & 5.67 & 5.70 & & & & 5.77 \\
\hline $\mathrm{Tb}$ & 0.86 & & 0.87 & & & 0.93 & 0.89 & & & & 0.94 \\
\hline Dy & 4.84 & & 4.73 & & & 5.23 & 4.93 & & & & 5.32 \\
\hline Ho & 0.87 & & 0.91 & & & 0.97 & 0.96 & & & & 0.97 \\
\hline $\mathrm{Er}$ & 2.37 & & 2.24 & & & 2.43 & 2.47 & & & & 2.51 \\
\hline $\mathrm{Tm}$ & 0.28 & & 0.31 & & & 0.30 & 0.30 & & & & 0.33 \\
\hline $\mathrm{Yb}$ & 1.80 & & 1.70 & & & 1.90 & 1.80 & & & & 2.00 \\
\hline $\mathrm{Lu}$ & 0.26 & & 0.36 & & & 0.28 & 0.37 & & & & 0.26 \\
\hline
\end{tabular}

(1) XRF analyses carried out at the University of Catania

(2) ICP-MS analyses carried out at SGS Mineral Services, Toronto, Canada 
Table $3 \mathrm{Sr}-\mathrm{Nd}$ isotopic compositions of Leonforte alkali basalts

\begin{tabular}{|c|c|c|c|c|c|c|c|c|c|c|c|}
\hline Sample & $\mathrm{Rb}(\mathrm{ppm})$ & $\mathrm{Sr}(\mathrm{ppm})$ & ${ }^{87} \mathrm{Rb} /{ }^{86} \mathrm{Sr}$ & ${ }^{87} \mathrm{Sr} /{ }^{86} \mathrm{Sr}$ & $\left({ }^{87} \mathrm{Sr} /{ }^{86} \mathrm{Sr}\right)_{i}$ & $\mathrm{Sm}(\mathrm{ppm})$ & $\mathrm{Nd}(\mathrm{ppm})$ & ${ }^{147} \mathrm{Sm} /{ }^{144} \mathrm{Nd}$ & ${ }^{143} \mathrm{Nd} /{ }^{144} \mathrm{Nd}$ & $\mathrm{Nd}_{i}$ & $\varepsilon \mathrm{Nd}_{(t)}$ \\
\hline VG 1 & 23.1 & 600 & $0.1113 \pm 5$ & $0.706040 \pm 34$ & 0.7057 & 6.10 & 24.97 & $0.1476 \pm 8$ & $0.512827 \pm 16$ & 0.512605 & 5.13 \\
\hline VG11 & 25.9 & 519 & $0.1434 \pm 6$ & $0.706654 \pm 52$ & 0.7062 & 5.11 & 21.87 & $0.1412 \pm 8$ & $0.512814 \pm 10$ & 0.512602 & 5.08 \\
\hline
\end{tabular}

Uncertainties are given as $2 \mathrm{SD}$ to the least significant digits. $\mathrm{Sr}_{i}$ and $\varepsilon \mathrm{Nd}_{(t)}$ values are calculated at $t=230 \mathrm{Ma}$
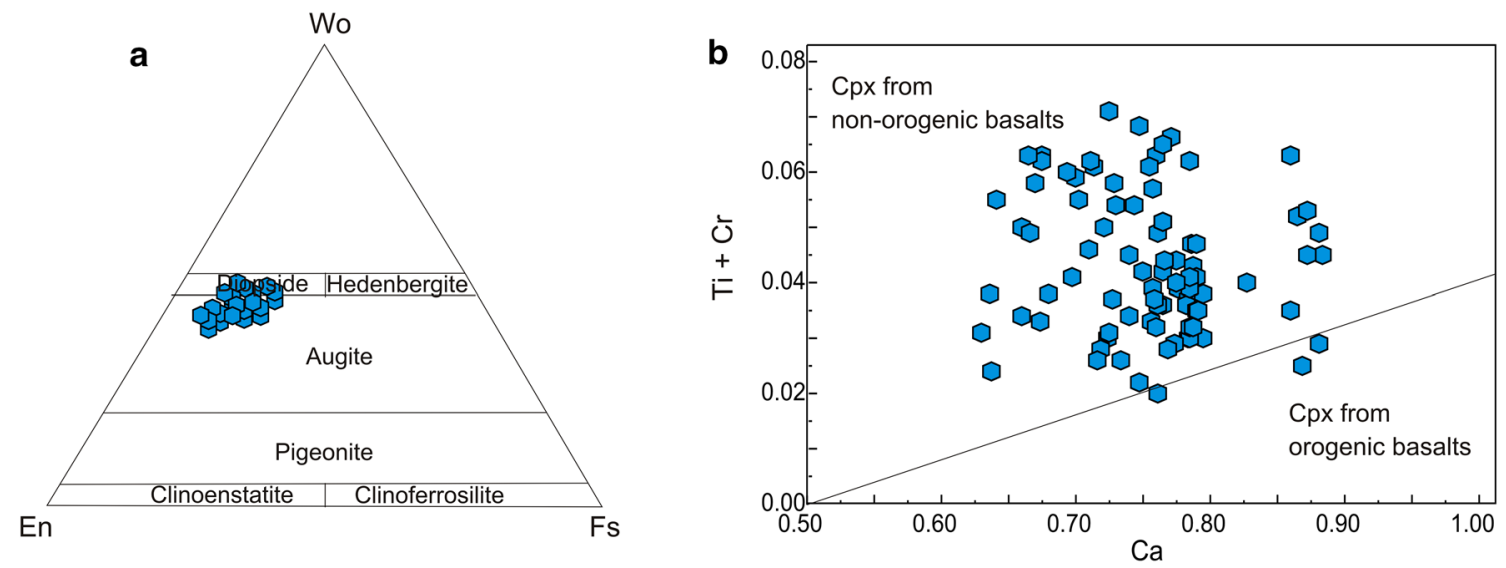

Fig. 3 a Clinopyroxene composition in the Wo-En-Fs (Morimoto 1988) and b the Ti + Cr versus Ca (Leterrier et al. 1982) classification diagrams. Fields of clinopyroxene compositions from orogenic and non-orogenic basalts are from Leterrier et al. (1982)

chlorite replacement. Ilmenite, apatite and very few zircon and titanite grains occur as accessory phases. Secondary products consist of epidote, calcite and sporadic radial prehnite crystals filling fractures and forming "comb-like" structures.

\section{Whole-rock chemistry}

Post-emplacement alteration variably modified the pristine composition of the studied rocks, causing loss or addition of some of the most mobile elements (e.g., $\mathrm{K}, \mathrm{Na}, \mathrm{Rb}, \mathrm{Sr}$, $\mathrm{Ba}, \mathrm{Cs}, \mathrm{Pb}$ ) and an increase in the LOI (Table 2). These characteristics have been already reported for slightly younger tholeiitic basalts from Lercara area (western Sicily, Fig. 1; Cirrincione et al. 2014), as well as for nearly all the other middle-late Triassic basalts from the Mediterranean area (Fig. 4). For these reasons, the following discussion of the geochemical data is mostly based on the ratios of immobile, or least mobile, elements.

In this view, following the $\mathrm{Zr} / \mathrm{TiO}_{2}$ versus $\mathrm{Nb} / \mathrm{Y}$ classification diagram (Pearce 1996 after Winchester and Floyd 1977; Fig. 5), the Leonforte samples can be classified as alkali basalts. For comparison purposes, the fields of middle to late Triassic anorogenic sub-volcanic rocks with similar composition from Sardinia-Corsica Domain, Northern Calabria and Imerese Basin (Western Sicily) have been drawn in the same diagram. Dykes from Sardinia-Corsica

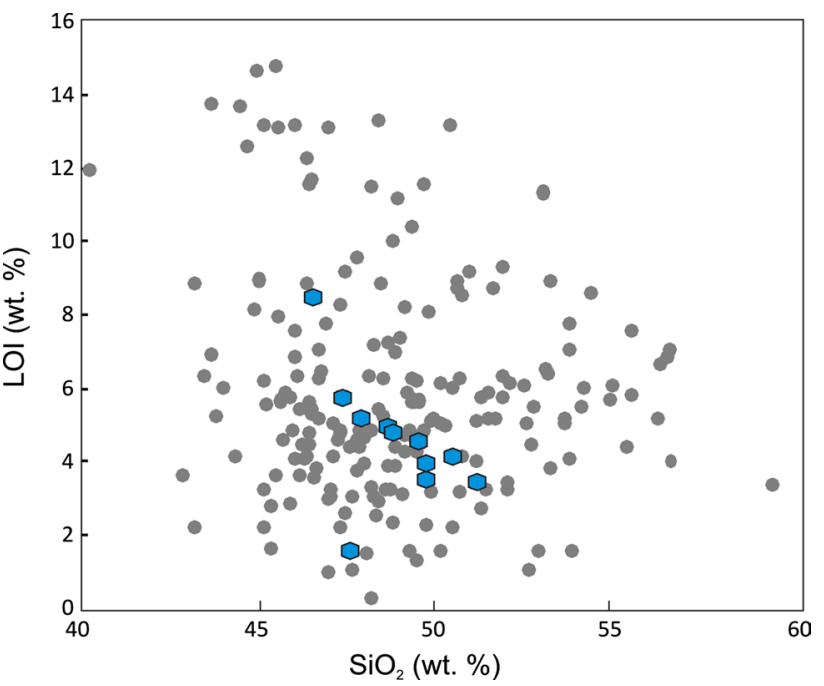

Fig. 4 LOI versus $\mathrm{SiO}_{2}$ (normalized to $100 \mathrm{wt} \%$, volatile free) diagram for Leonforte alkali basalts (hexagons) compared with various middle-late Triassic alkali basalts (circles) from the Mediterranean area; reference data are from Floyd (1993), Pe-Piper (1998), Floyd et al. (2000), Cortesogno et al. (2004), Genç (2004), Pomonis et al. (2004), Lapierre et al. (2007), Maury et al. (2008), Sayit and Göncüoglu (2009), Barca et al. (2010), Sayit et al. (2010), Chauvet et al. (2011), Slovenec et al. (2011), Sanz et al. (2013)

Domain include 240-230 Ma alkaline basaltic types (Vaccaro et al. 1991; Buraglini and Traversa 2000; Traversa et al. 2003), dykes from Northern Calabria consist 


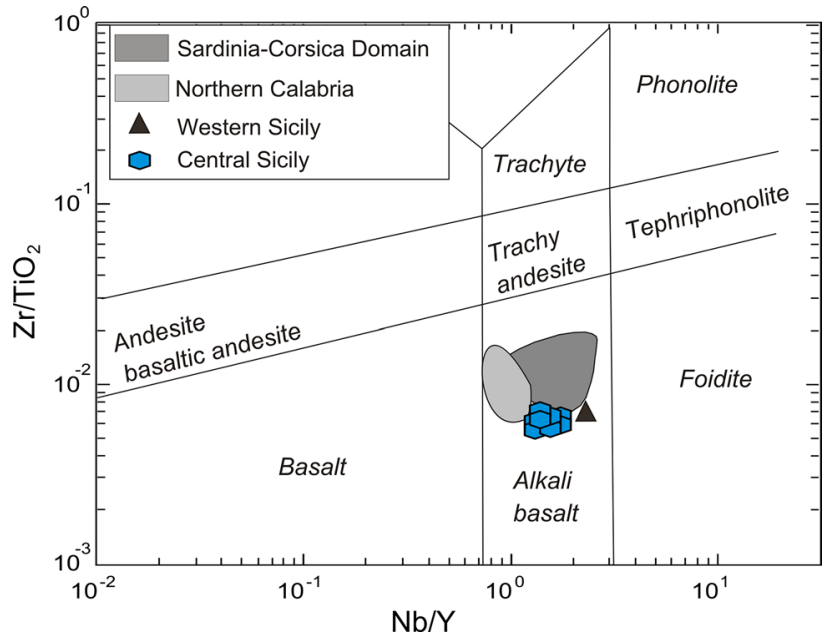

Fig. $5 \mathrm{Zr} / \mathrm{TiO}_{2}$ versus $\mathrm{Nb} / \mathrm{Y}$ diagram (Pearce 1996; after Winchester and Floyd 1977) for Leonforte rocks (hexagons). Triassic alkali basalts from northern Calabria, Sardinia-Corsica Domain (SCD) and Western Sicily are from Barca et al. (2010), Traversa et al. (2003) and Guarnieri et al. (2000), respectively

of middle Triassic alkali basalts from the San Donato Unit (Barca et al. 2010), while Western Sicily alkali basaltic pillow lavas from Termini Imerese area (Fig. 1) have been dated as Late Triassic-Early Jurassic ( 197 Ma; whole-rock and plagioclase fraction K-Ar ages; Guarnieri et al. 2000).

The Leonforte alkali basalts are characterized by high $\mathrm{Fe}_{2} \mathrm{O}_{3 \text { tot }}(11.30-13.87 \mathrm{wt} \%)$ and variable $\mathrm{MgO}$ contents (5.41-10.14 wt\%), with $\mathrm{Mg} \#\left[\mathrm{Mg} /\left(\mathrm{Mg}+\mathrm{Fe}^{2+}\right)\right.$, assuming $\left.\mathrm{Fe}_{2} \mathrm{O}_{3} / \mathrm{FeO}=0.15\right]$ ranging between 47 and 60. The $\mathrm{Mg \#}$ values, as well as the low $\mathrm{Cr}(51-200 \mathrm{ppm})$ and $\mathrm{Ni}$ contents (48-136 ppm), indicate a relatively evolved composition. They are enriched in highly incompatible elements (e.g., $\mathrm{La}_{\mathrm{N}}=61-76$ ), with only limited REE fractionation $\left(\mathrm{La}_{\mathrm{N}} / \mathrm{Yb}_{\mathrm{N}}=7.4-8.8\right.$; Fig. $\left.6 \mathrm{a}\right)$ and a slightly positive $\mathrm{Eu}$ anomaly $\left(\mathrm{Eu} / \mathrm{Eu}^{*}=1.06-1.13\right)$. They show a close similarity with classical HIMU-OIB magmas (e.g., St. Helena alkali basalts; Kawabata et al. 2011; Fig. 6a), especially for HREE contents, as also visible in the primitive mantle-normalized incompatible element diagram (Fig. 6b). The strongest difference between the studied samples and St. Helena basalts is the lack of the typical Pb-negative anomaly. High LREE and HFSE concentrations, coupled with high HFSE/LILE ratios, support an anorogenic nature of the magmas (e.g., Lustrino and Wilson 2007; Kawabata et al. 2011).

A tight similarity can be also observed between the trace element patterns of the Leonforte samples and Triassic alkali basalts of similar composition, from the Sardinia-Corsica Domain (Traversa et al. 2003), northern Calabria (Barca et al. 2010) and western Sicily (Guarnieri et al. 2000), which are considered as typical intraplate

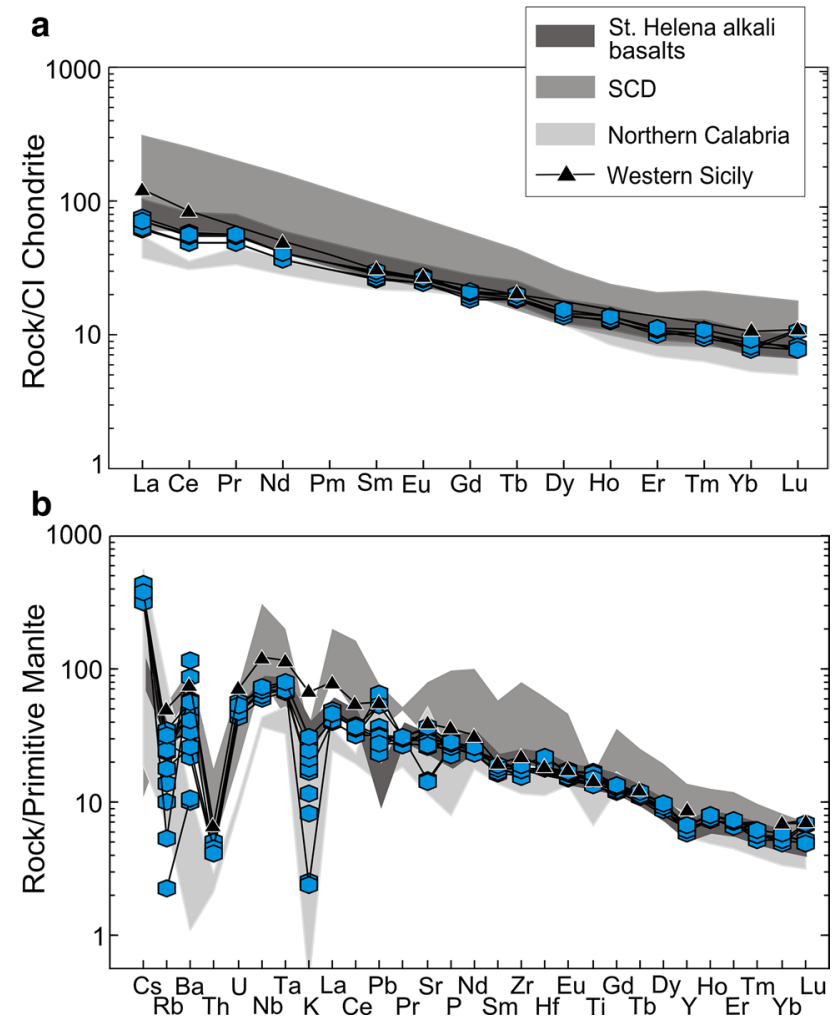

Fig. 6 a REE, b multi-element patterns normalized to chondrite (Nakamura 1974) and primitive mantle (Lyubetskaya and Korenaga 2007) compositions, respectively. St. Helena alkali basalts, Western Sicily, SCD and Northern Calabria alkali basalts are from Kawabata et al. (2011), Guarnieri et al. (2000), Traversa et al. (2003) and Barca et al. (2010), respectively

manifestations associated with the first phases of continental breakup and Alpine Tethys ocean spreading.

\section{$\mathrm{Sr}-\mathrm{Nd}$ isotope results}

The initial $\mathrm{Nd}$ isotope ratios have been age-corrected to $230 \mathrm{Ma}$ on the basis of field relationships (Grasso and Scribano 1985). The recalculated ratios of the two least altered alkali basalt samples are indistinguishable, as expected for two samples of the same rock. Changing the assumed emplacement ages by a few tens of Ma (e.g., 190-270 Ma) would result in negligible shifts of the recalculated initial isotopic ratios, especially the $\varepsilon_{\mathrm{Nd}}$. From the $\mathrm{Sm} / \mathrm{Nd}$ element ratio and the $\mathrm{Nd}$ isotopic composition, we calculated a single-stage model age $t_{\mathrm{DM}(\mathrm{Nd})}=0.7 \mathrm{Ga}$ for both samples. Their identity for the Leonforte samples suggests that the $\mathrm{Sm}-\mathrm{Nd}$ system has remained pristine and their value indicates that the contamination with crustal components was small, even if detectable (if samples had been uncontaminated depleted mantle melts, by definition they should have model ages of $0.23 \mathrm{Ga}$ ). What the model 


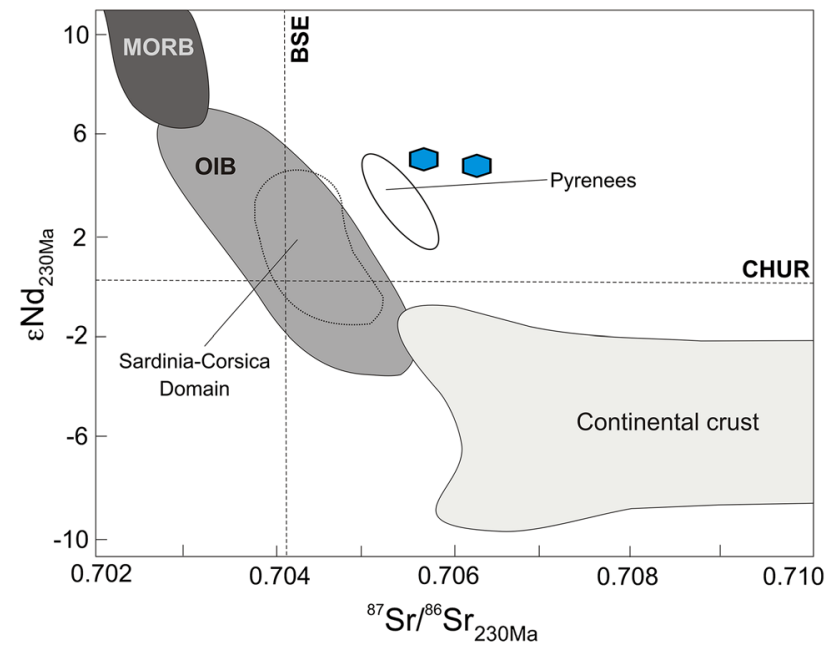

Fig. $7 \varepsilon \mathrm{Nd}_{t}$ versus ${ }^{87} \mathrm{Sr} /{ }^{86} \mathrm{Sr}_{i}$ diagram for studied Leonforte samples. MORB and OIB fields after Lustrino and Wilson (2007). Compositional fields of alkali basalts Sardinia-Corsica Domain after Traversa et al. (2003) and Orejana et al. (2008 and references therein); fields of alkali basalts from Pyrenees and continental crust field after Orejana et al. (2008, and references therein)

ages cannot discriminate is whether the admixture of some crustal $\mathrm{Nd}$ (which, because of the relative mass balance of $\mathrm{Nd}$ concentrations in crust and mantle, corresponds to a few percent crustal components at the very most) occurred by metasomatic enrichment of the mantle source or by assimilation of crustal wall rocks by the ascending magma.

Unlike the initial $\mathrm{Nd}$ isotope ratios, the two initial $\mathrm{Sr}$ isotope ratios differ by about 12 SDs (0.7057-0.7062). Moreover, the $t_{\mathrm{DM}(\mathrm{Sr})}$ that can be calculated for the present rocks (following Buettner et al. 2005) are 2.6 and $2.3 \mathrm{Ga}$, in gross contrast with the geological context and the $t_{\mathrm{DM}(\mathrm{Nd})}$. This is evidence of a massive perturbation of the $\mathrm{Rb}-\mathrm{Sr}$ system, due to the mobility of $\mathrm{Rb}$ and $\mathrm{Sr}$ during post-magmatic alteration. Alteration commonly leaches more $\mathrm{Rb}$ than $\mathrm{Sr}$ from the rock, resulting in a lower $\mathrm{Rb} / \mathrm{Sr}$ ratio in the altered rock. Moreover, interaction with ocean water would further increase the $\mathrm{Sr}$ isotope ratio. We therefore suggest that the measured $\mathrm{Rb} / \mathrm{Sr}$ ratios are likely lower than the original ones and, as a consequence, the recalculated initial ${ }^{87} \mathrm{Sr} /{ }^{86} \mathrm{Sr}$ isotopic ratios are to be considered as maximum estimates only.

The age-corrected ${ }^{143} \mathrm{Nd} /{ }^{144} \mathrm{Nd}_{i}$ ratios are $\sim 0.51260$, higher than CHUR at $230 \mathrm{Ma}$. In the $\varepsilon_{\mathrm{Nd}_{i}}$ versus $\left({ }^{87} \mathrm{Sr} /{ }^{86} \mathrm{Sr}\right)_{i}$ diagram (Fig. 7), samples plot in the "forbidden" first quadrant, as an artifact of the disturbance(s) of the Rb-Sr system. Their pristine compositions are likely to have been analogous to those of similar sub-volcanic rocks, such as the Late Triassic alkali basalts from Sardinia-Corsica Domain (Traversa et al. 2003) and Turkey (Antalya Nappe; Maury et al. 2008).

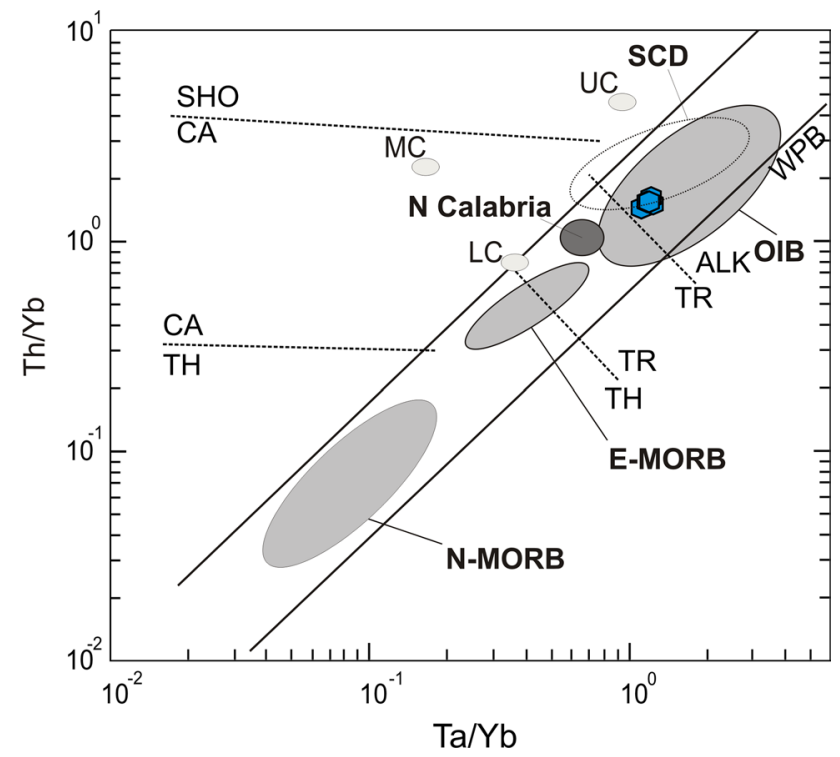

Fig. $8 \mathrm{Th} / \mathrm{Yb}$ versus $\mathrm{Ta} / \mathrm{Yb}$ diagram (Pearce 1982). N-, E-MORB and OIB after Sun and McDonough (1989); UC, LC, MC upper, lower and middle crust, respectively (Rudnick and Fountain 1995), SCD Sardinia-Corsica Domain alkali basalts (Traversa et al. 2003), N Calabria: San Donato alkaline dykes (Barca et al. 2010)

\section{Discussion}

Alkali basalts from Leonforte area show poorly fractionated MREE/HREE patterns $\left(\mathrm{Tb}_{\mathrm{N}} / \mathrm{Yb}_{\mathrm{N}}=0.69-0.76\right)$ ruling out the presence of residual garnet in the source. Besides, they are strongly enriched in highly incompatible elements and have bell-shaped patterns in primitive mantle-normalized diagrams, with positive anomalies at $\mathrm{Nb}-\mathrm{Ta}$, as typical for sodic alkaline intra-plate magmas (Lustrino et al. 2011; Pilet et al. 2011; Stracke 2012). Furthermore, $\mathrm{Th} / \mathrm{Yb}$ and $\mathrm{Ta} / \mathrm{Yb}$ ratios (Fig. 8) are compatible with a derivation from an enriched mantle source that suffered little, if any, crustal involvement. Such evidence is also confirmed by the high HFSE/LILE ratios and the similarity between the studied rocks and the classical OIB of St. Helena (Kawabata et al. 2011; Fig. 6b).

High $\varepsilon_{\mathrm{Nd}}$ values such as those shown by the Leonforte sill require a derivation from a mantle source such as MORB or OIB. The low Nd/Sm ratio contrasts with the trace element pattern of the alkaline rocks that implies a derivation from an incompatible element-enriched mantle source. This decoupling of the elemental and isotopic signature of the rocks is commonly observed in all mid-plate sodic alkaline rocks (e.g., Lustrino and Wilson 2007). The incompatible trace element ratios can be easily modified either during metasomatic events related to interaction with LILE- and LREE-rich fluids/melts (Lago et al. 2004; Obst et al. 2004) or during chromatographic reactions in the form of zone-refining processes during upwelling of 

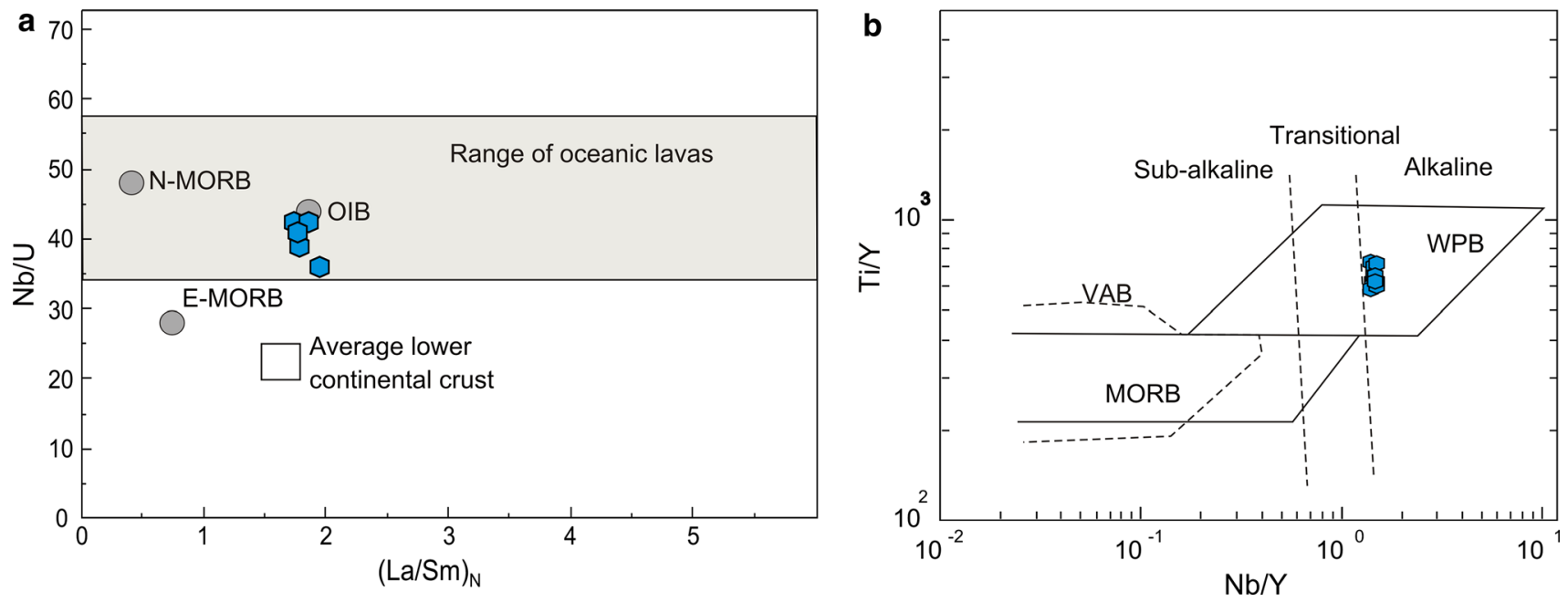

Fig. 9 a $\mathrm{Nb} / \mathrm{U}$ versus $(\mathrm{La} / \mathrm{Sm})_{\mathrm{N}}$ for studied samples. The gray field displays the variation of $\mathrm{Nb} / \mathrm{U}$ ratio in oceanic lavas (Hofmann et al. 1986). Average composition of lower continental crust is from Rudnick and Fountain (1995). E-, N-MORB and OIB compositions are

basaltic melts, following the model described by Adam and Green (2011). Indeed, the volume of peridotite that is crossed by partial melts may transfer into the melt the incompatible element budget (usually modest at average global scale for the uppermost mantle). During this element exchange, the original MORB-like compositions can evolve up to HIMU-OIB-like signatures (Adam and Green 2011). Alternative views (e.g., Kamber and Collerson 1999; Collerson et al. 2010; Li et al. 2014) consider the diverse OIB magma compositions as source-inherited and reflecting varying degrees of a two-stage binary mixing involving only two reservoirs: the depleted upper mantle and the enriched (i.e., never tapped by partial melting) lowermost mantle, the latter variably contaminated with subducted material that pierced the Transition Zone.

As previously discussed, the absence of negative anomalies in HFSE, the relatively low LILE/HFSE and LREE/ HFSE ratios in primitive mantle-normalized multi-element plots (Fig. 6b) and the overall pattern similar to St. Helena basalts indicate minor if any interaction with subduction-modified mantle sources. The absence of negative $\mathrm{Pb}$ anomalies is the only substantial difference with typical OIB magmas. Here this difference is considered mostly reflecting post-magmatic incorporation of seawater $\mathrm{Pb}$, rather than intense crustal contamination, because key ratios of immobile trace elements, such as $\mathrm{Ta} / \mathrm{Yb}, \mathrm{Th} /$ $\mathrm{Yb}, \mathrm{Nb} / \mathrm{U}$ and $\mathrm{Nb} / \mathrm{Y}$ (Figs. 8, 9), are very similar to those of typical oceanic lavas, not significantly affected by interaction with continental crustal material (Hofmann et al. 1986). It is, however, to be noticed that subtle evidences of crustal contamination, compatible with assimilation of small amount of wall rocks during magma ascent, may from Humpris et al. (1985) and Sun and McDonough (1989), respectively. b Ti/Y versus Nb/Y diagram (Pearce 1982). WPB within-plate basalts, MORB mid-ocean ridge basalts, $V A B$ volcanic arc basalts

arise from the shift of the $\mathrm{Nb} / \mathrm{U}$ ratios toward typical lower crust values, as well as from the $\mathrm{Nd}$ model ages indicating incorporation of older crustal material.

Trace element and Nd isotopic data are, on the whole, consistent with an origin of the Leonforte sill by lowdegree partial melting of an asthenospheric mantle source enriched after percolation of metasomatizing fluids/melts. Geochemical features (e.g., the Ti/Y vs. Nb/Y discrimination diagram, Fig. 9b) clearly suggest a within-plate, anorogenic, tectonic setting.

Anorogenic Late Triassic sodic alkaline melts of similar geochemical and isotopic characteristics are documented in several former Laurasian (Sardinia-Corsica Domain, e.g., Traversa et al. 2003; Western Alps, e.g., Monjoie et al. 2005; Pyrenees, e.g., Lago et al. 2004, SE Iberian Ranges, e.g., Lago et al. 2012; Northern Calabria, e.g., Barca et al. 2010; Greece, e.g., Pe-Piper 1998; Bortolotti et al. 2008) and Gondwanan continental margins (Cyprus, Lapierre et al. 2007; Syria, Al-Riyami and Robertson 2002; Turkey, Maury et al. 2008; Oman, Chauvet et al. 2011).

In contrast, the Leonforte alkali basalts show completely different whole-rock and mineralogical compositions compared with the coeval igneous products cropping out in the Southern Alps (e.g., Dolomites, Brescian Prealps), that were also part of the nascent North African margin. Here Ladinian potassic rocks (with basic to acid compositions and mostly shoshonitic to K-calcalkaline affinity) are associated with drowning carbonate platforms, representing marine transgression (e.g., Cassinis et al. 2008; Bellieni et al. 2010). Early studies associated such compositions with an ensialic orogenic event (Castellarin et al. 1988). Alternatively, the subduction-related features of the 
Southern Alps volcanic rocks have been interpreted as the effect of a back-arc setting of an active subduction system (Armienti et al. 2003), similarly to what recently proposed for the Ladinian plutonic rocks in the Western Alps (Finero body; Zanetti et al. 2013). On the other hand, the geochemical characteristics of Ladinian igneous rocks in Southern Alps have been more properly interpreted in light of a derivation from mantle sources, modified by older subduction events, in a transtensional setting (e.g., Sloman 1989; Bonadiman et al. 1994; Cassinis et al. 2008; Bellieni et al. 2010).

The studied rocks from central Sicily provide another evidence of the sodic alkaline magmatism associated with the intra-continental extensional processes and crustal thinning following the collapse of the Variscan Orogen. Our data do not provide unequivocal constraints useful to infer passive versus active rifting mechanisms connected with this magmatic activity, but the strong similarities with coeval alkali basalts emplaced along former orogenic sutures suggest a common origin involving passive mantle upwelling following the tectonic collapse of the Variscan Orogenic Belt.

What emerges clearly is that dismembering Pangea was characterized by very variable magma types along its passive margins. At the same time, calcalkaline to potassic and ultrapotassic magma production characterized the northern sector of the Adria sub-plate while the southern sectors, represented by the present-day central Sicily, were characterized by mildly sodic alkaline volcanic activity.

The geochemical features of the Leonforte alkali basalts may be interpreted in the view of the late Triassic paleogeographic reconstruction of the western part of the Neotethys realm by Sanz et al. (2013), envisaging the presence of a vast epicontinental platform whose southeastern parts (e.g., southern France, Sardinia and Catalonian Coastal Range) were characterized by a thinner crust, allowing melting of asthenospheric mantle and little interaction with crustal components; conversely, the northwestern parts (e.g., NW Iberian Chain, External Betics and Brescian Prealps) were characterized by a greater crustal thickness, favouring melting in the subcontinental lithospheric mantle and greater crustal contamination.

The above interpretation is consistent with location of central Sicily at the westernmost extremity of the Neotethys Ocean, formed when the Cimmerian terrane broke off along the NW margin of Gondwana, drifting northward to eventually collide with the southern Eurasian margin (e.g., Stampfli et al. 2013).

By taking into account also the age of the magmatic products, a general pattern can be inferred in the spatialtemporal distribution of the Permo-Triassic basic magmatism in whole SW Europe. The change from late Variscan post-collisional extension to post-Variscan rifting associated with Pangea breakup was marked by intrusion of alkaline magmas beginning, in some SW European areas, in the Late Permian. This igneous activity eventually evolved up to the Atlantic Ocean early opening marked, in turn, by transition from alkaline to tholeiitic magmas in the Late Triassic (e.g., Orejana et al. 2008 and references therein).

Valuable pieces of information about the chronological evolution of the Permo-Triassic basic magmas affinity and their geographic distributions in SW Europe are now provided by the data recently obtained for Calabria (Barca et al. 2010) and Sicily (Cirrincione et al. 2014; this study). In particular, the Leonforte rocks would be part of those products marking the transition from post-orogenic extension to an anorogenic setting (at $\sim 230 \mathrm{Ma}$ ) associated with the early phases of continental rifting. After this transition stage, a new more abundant igneous activity, associated with the first oceanization events, affected the same margins producing the tholeiitic basalts of the Central Atlantic Magmatic Province ( 200 Ma), which is likely to include also those presently cropping out in Western Sicily (Cirrincione et al. 2014), not far from the Leonforte sill.

\section{Concluding remarks}

The late- to post-orogenic evolution of the Variscan belt was associated with gravitational collapse of the thickened crust, and several models have been proposed to explain the tectonic mechanisms (e.g., Ziegler et al. 2001; Stampfli and Borel 2002). Widespread magmatism was associated with this extensional phase and affected SW Europe since the early stages, with the production of calcalkaline magmatic rocks (e.g., Cortesogno et al. 1998; Cassinis et al. 2008; Bellieni et al. 2010; Romano et al. 2011 and reference therein) up to Late Permian-Late Triassic when a shift to sodic alkaline affinity took place in most of the collapsing Variscides (Bonin et al. 1998; Cortesogno et al. 1998), eventually evolving around the Triassic-Jurassic boundary to tholeiitic compositions (e.g., Cirrincione et al. 2014, and references therein).

Triassic alkaline rocks from central Sicily exhibit some typical geochemical and isotopic features, such as the positive $\mathrm{Nb}-\mathrm{Ta}$ anomaly and positive $\varepsilon_{\mathrm{Nd}_{i}}$ values, indicating a negligible involvement of the thinned continental crust and a significant contribution from the upwelling asthenospheric mantle. $\mathrm{Rb}-\mathrm{Sr}$ systematics indicates post-magmatic depletion of $\mathrm{Rb}$ with respect to $\mathrm{Sr}$, resulting in highly positive $\varepsilon_{\mathrm{Sr}_{i}}$. The studied basalts show a distinctive OIB-like incompatible element signature (enrichments in LILE, HFSE and LREE), suggesting an anorogenic nature of the magmas, with no or very little involvement of crustal and/ or subduction-related components. 
As a whole, the $\mathrm{Nd}$ isotopic composition of the rocks and the least mobile incompatible element contents and ratios are compatible with low-degree partial melting of a moderately enriched asthenospheric mantle source, possibly due to the metasomatizing effects of percolating fluids/ melts. The results do not allow unequivocal interpretations about the nature and origin of these metasomatizing agents, or the passive versus active rifting mechanism involved in the Pangea breakup and subsequent Tethys opening, but the close similarity of these rocks with anorogenic products of similar composition, emplaced in the same geodynamic context in other sectors of the SW Variscan European chain, suggests a common origin related, at least in part, to the tectonic collapse of the Variscan Orogen.

Acknowledgments Rosanna Maniscalco and Giovanni Sturiale are thanked for providing geological and stratigraphic information on the study area. Marcello Serracino (CNR-IGAG, Rome) is thanked for his usual skill during microprobe analyses. The manuscript strongly benefitted from reviews by Ioan Seghedi and Gerhard Franz, as well as from the editorial handling and suggestions by Christoph Breitkreuz. Samuele Agostini is thanked for his comments on a previous version of this manuscript. The authors would like to express special thanks to Professor Wolf-Christian Dullo for his constructive and helpful editorial handling. Financial support from University of Catania (R.C., Fondi Ateneo 2009; P.F., Fondi Ateneo 2012; V.R., PhD grants; A.T., Fondi Ateneo, 2010), La Sapienza University of Rome (M.L., Fondi Ateneo 2014) and MIUR (M.L., PRIN 2010 Research Grant 20107ESMX9_001) is gratefully acknowledged.

\section{References}

Adam J, Green T (2011) Trace element partitioning between micaand amphibole-bearing garnet lherzolite and hydrous basanitic melt: Tasmanian Cenozoic basalts and the origins of intraplate basaltic magmas. Contrib Mineral Petrol 161:883-899

Al-Riyami K, Robertson A (2002) Mesozoic sedimentary and magmatic evolution of the Arabian continental margin, northern Syria: evidence from the Baer-Bassit Melange. Geol Mag 139:395-420

Anderson DL (2011) Hawaii, boundary layers and ambient mantlegeophysical constraints. J Petrol 52:1547-1577

Anderson DL (2013) The persistent mantle plume myth. Austr J Earth Sci 60:657-673

Appel P, Cirrincione R, Fiannacca P, Pezzino A (2011) Age constraints on Late Paleozoic evolution of continental crust from electron microprobe dating of monazite in the Peloritani Mountains (southern Italy): another example of resetting of monazite ages in high-grade rocks. Int J Earth Sci 100:107-123

Armienti P, Corazzato C, Groppelli G, Natoli E, Pasquarè G (2003) Geological and Petrographical study of Montecampione Triassic subvolcanic bodies (Southern Alps, Italy): preliminary geodynamic results. Boll Soc Geol It Vol Spec 2:67-78

Avanzinelli R, Sapienza GT, Conticelli S (2012) The Cretaceous to Paleogene within-plate magmatism of Pachino-Capo Passero (southeastern Sicily) and Adria (La Queglia and Pietre Nere, southern Italy): geochemical and isotopic evidence against a plume-related origin of circum-Mediterranean magmas. Eur $\mathbf{J}$ Mineral 24:73-96
Barca D, Cirrincione R, De Vuono E, Fiannacca P, Ietto F, Lo Giudice A (2010) The Triassic rift system in the northern CalabrianPeloritani Orogen: evidence from basaltic dyke magmatism in the San Donato Unit. Period Mineral 79:61-72

Beccaluva L, Coltorti M, Saccani E, Siena F, Zeda O (2005) Triassic magmatism and Jurassic ophiolites at the margins of the Adria Plate. In: Finetti IR (ed) CROP project: deep seismic exploration of the Central Mediterranean and Italy. Elsevier, Amsterdam, pp 607-621

Bellia S, Lucido G, Nuccio PM, Valenza M (1982) Magmatismo in area trapanese in relazione all'evoluzione geodinamica della Tetide. Rend Soc It Mineral Petrol 38:163-174

Bellieni G, Fioretti AM, Marzoli A, Visonà D (2010) Permo-Paleogene magmatism in the Eastern Alps. Rend Fis Acc Lincei 21:51-71

Bonadiman C, Coltorti M, Siena F (1994) Petrogenesis and T- $\mathrm{fO}_{2}$ estimates of Mt. Monzoni complex (Central Dolomites, Southern Alps): a Triassic shoshonitic intrusion in a transcurrent geodynamic setting. Eur J Mineral 6:943-966

Bonin B, Azzouni-Sekkal A, Bussy F, Ferrag S (1998) Alkali-calcic and alkaline post-orogenic (PO) granite magmatism: petrologic constraints and geodynamic settings. Lithos 45:45-70

Bortolotti V, Principi G (2005) Tethyan ophiolites and Pangea breakup. Isl Arc 14:442-470

Bortolotti V, Chiari M, Marcucci M, Photiades A, Principi G, Saccani E (2008) New Geochemical and age data on the ophiolites from the Othrys area (Greece): implication for the Triassic evolution of the Vardar ocean. Ofioliti 33:135-151

Buettner A, Kleinhanns IC, Rufer D, Hunziker JC, Villa IM (2005) Magma generation at the easternmost section of the Hellenic arc: $\mathrm{Hf}, \mathrm{Nd}, \mathrm{Pb}$ and $\mathrm{Sr}$ isotope geochemistry of Nisyros and Yali volcanoes (Greece). Lithos 83:29-46

Buraglini N, Traversa G (2000) Petrology and mineral chemistry of late-Hercynian dykes from NW Corsica (France). Period Mineral 69:269-310

Carminati E, Lustrino M, Doglioni C (2012) Geodynamic evolution of the central and western Mediterranean: Tectonics vs. igneous petrology constraints. Tectonophysics 579:173-192

Carrillat A, Martini R (2009) Palaeoenvironmental reconstruction of the Mufara Formation (Upper Triassic, Sicily): high resolution sedimentology, biostratigraphy and sea-level changes. Palaeogeogr Palaeocl 283:60-76

Cassinis G, Cortesogno L, Gaggero L, Perotti CR, Buzzi L (2008) Permian to Triassic geodynamic and magmatic evolution of the Brescian Prealps (eastern Lombardy, Italy). Boll Soc Geol It 127:501-518

Castellarin A, Lucchini F, Rossi PL, Selli L, Simboli G (1988) The Middle Triassic magmatic-tectonic arc development in the Southern Alps. Tectonophysics 146:79-89

Cella F, Cirrincione R, Critelli S, Mazzoleni P, Pezzino A, Punturo R, Fedi M, Rapolla A (2004) Gravity modeling in fold-thrust belts: an example from the Peloritani Mountains, southern Italy. Int Geol Rev 46:1042-1050

Chauvet F, Lapierre H, Maury RC, Bosch D, Basile C, Cotten J, Brunet P, Campillo S (2011) Triassic alkaline magmatism of the Hawasina Nappes: post-breakup melting of the Oman lithospheric mantle modified by the Permian Neotethyan Plume. Lithos 122:122-136

Cirrincione R (1996) Geochronologic and petrologic features of porphyrite rocks in the Tortonian conglomerate of north-eastern Sicily: hypothesis on their provenance. Period Mineral 65:21-33

Cirrincione R, Fiannacca P, Lo Giudice A, Pezzino A (2005) Evidence of early Palaeozoic continental rifting from mafic metavolcanics of southern Peloritani Mountains (North-Eastern Sicily, Italy). Ofioliti 30:15-25 
Cirrincione R, Fazio E, Fiannacca P, Ortolano G, Punturo R (2009) Microstructural investigation of naturally deformed leucogneiss from an Alpine shear zone (Southern Calabria-Italy). Pure Appl Geophys 166:1-16

Cirrincione R, Fazio E, Ortolano G, Pezzino A, Punturo R (2012) Fault-related rocks: deciphering the structural-metamorphic evolution of an accretionary wedge in a collisional belt, NE Sicily. Int Geol Rev 54:940-956

Cirrincione R, Fiannacca P, Lustrino M, Romano V, Tranchina A (2014) Late Triassic tholeiitic magmatism in Western Sicily: possible extension of the Central Atlantic Magmatic Province (CAMP) in the Central Mediterranean area. Lithos 188:60-71

Collerson KD, Williams Q, Ewart AE, Murphy DT (2010) Origin of HIMU and EM-1 domains sampled by ocean island basalts, kimberlites and carbonatites: the role of $\mathrm{CO}_{2}$-fluxed lower mantle melting in thermochemical upwellings. Phys Earth Planet Int 181:112-131

Cordery MJ, Davies GF, Campbell IH (1997) Genesis of flood basalts from eclogite-bearing mantle plumes. J Geophys Res 102:20179-20197

Cortesogno L, Cassinis G, Dallagiovanna G, Gaggero L, Oggiano G, Ronchi A, Seno S, Vanossi M (1998) The post-Variscan volcanism in the Late Carboniferous-Permian sequences of Ligurian Alps, Southern Alps and Sardinia. Lithos 45:305-328

Cortesogno L, Gaggero L, Yanev S (2004) Anorogenic volcanism in the Triassic sequences at the boundary of the Moesian plate. Geodin Acta 17:55-69

Courtillot V, Davaille A, Besse J, Stock J (2003) Three distinct types of hotspots in the Earth's mantle. Earth Planet Sci Lett 205:295-308

Doglioni C, Carminati E, Bonatti E (2003) Rift asymmetry and continental uplift. Tectonics. doi:10.1029/2002TC001459

Fiannacca P, Williams IS, Cirrincione R, Pezzino A (2013) The augen gneisses of the Peloritani Mountains (NE Sicily): Granitoid magma production during rapid evolution of the northern Gondwana margin at the end of the Precambrian. Gondwana Res 23:782-796

Floyd PA (1993) Geochemical discrimination and petrogenesis of alkalic basalt sequences in part of the Ankara melange, central Turkey. J Geol Soc 150:541-550

Floyd PA, Göncüoğlu MC, Winchester JA, Yaliniz MK (2000) Geochemical character and tectonic environment of Neotethyan ophiolitic fragments and metabasites in the Central Anatolian Crystalline Complex, Turkey. Geol Soc Spec Publ 173:183-202

Franzini M, Leoni L, Saitta M (1975) Revisione di una metodologia analitica per fluorescenza-X, basata sulla correzione completa degli effetti di matrice. Rend Soc It Mineral Petrol 31:365-378

Genç ŞC (2004) A Triassic large igneous province in the Pontides, northern Turkey: geochemical data for its tectonic setting. J Asian Earth Sci 22:503-516

Grasso M (2001) The Apenninic-Maghrebian orogen in southern Italy, Sicily and adjacent areas. In: Vai GB, Martini IP (eds) Anatomy of an Orogen: the Apennines and adjacent Mediterranean basins. Kluwer, Dordrecht, pp 225-286

Grasso M, Scribano V (1985) Geological and petrological notes on a Triassic sill on the southern slope of Mt. Altesina (Central Sicily): a contribution to the knowledge of the Triassic magmatism in Sicily. Boll Soc Geol It 104:229-238

Grasso M, Miuccio G, Maniscalco R, Garofalo P, La Manna F, Stamilla R (1995) Plio-Pleistocene structural evolution of the western margin of the Hyblean Plateau and the Maghrebian foredeep, SE Sicily. Implications for the deformational history of the Gela Nappe. Ann Tettonicae 9:7-21

Guarnieri P, Puglisi D, Balogh K (2000) Age and provenance of the pillow basalt exotics within the Eocene Imerese succession (North-Western Sicily). Mem Soc Geol It 55:235-241
Handy MR, Schmid SM, Bousquet R, Kissling E, Bernoulli D (2010) Reconciling plate-tectonic reconstructions of Alpine Tethys with the geological-geophysical record of spreading and subduction in the Alps. Earth Sci Rev 102:121-158

Hofmann AW, Jochum KP, Seufert M, White WM (1986) Nb and Pb in oceanic basalts: new constraints on mantle evolution. Earth Planet Sci Lett 79:33-45

Humpris SE, Thompson G, Schilling JG, Kingsley RA (1985) Petrological and geochemical variations along the MidAtlantic Ridge between $46^{\circ} \mathrm{S}$ and $32^{\circ} \mathrm{S}$ : influence of the Tristan de Cunha mantle plume. Geochim Cosmochim Acta 49:1445-1464

Kamber BS, Collerson KD (1999) Origin of ocean island basalts: a new model based on lead and helium isotope systematic. J Geophys Res 104:479-491

Kawabata H, Hanyu T, Chang Q, Kimura J, Nichols ARL, Tatsumi Y (2011) The petrology and geochemistry of St. Helena Alkali Basalts: evaluation of the oceanic crust-recycling model for HIMU OIB. J Petrol 52:791-838

Lago M, Arranz E, Pocovi A, Galè C, Gil-Imaz A (2004) Permian magmatism and basin dynamics in the southern Pyrenees: a record of the transition from late Variscan transtension to early Alpine extension. In: Wilson M, Neumann ER, Timmerman MJ, Heeremans M, Larsen BT (eds) Permo-Carboniferous magmatism and rifting in Europe. Geological Society, London, Special Publications 223, pp 465-490

Lago M, de la Horra R, Ubide T, Galé C, Galán-Abellán B, Barrenechea JF, López-Gómez J, Benito MI, Arche A, Alonso-Azcárate J, Luque FJ, Timmerman MJ (2012) First report of a MiddleUpper Permian magmatism in the SE Iberian Ranges: characterisation and comparison with coeval magmatisms in the western Tethys. J Iber Geol 38:331-348

Lapierre H, Bosch D, Narros A, Mascle GH, Tardy M, Demant A (2007) The Mamonia Complex (SW Cyprus) revisited: remnant of Late Triassic intra-oceanic volcanism along the Tethyan southwestern passive margin. Geol Mag 144:1-19

Lentini F, Carbone S, Catalano S (1994) Main structural domains of the central Mediterranean region and their Neogene tectonic evolution. Boll Geofis Teor Appl 36:141-144

Leterrier J, Maury R, Thonon P, Girard D, Marchal M (1982) Clinopyroxene composition as a method of identification of the magmatic affinities of paleo-volcanic series. Earth Planet Sci Lett 59:139-154

Li M, McNamara AK, Garnero EJ (2014) Chemical complexity of hotspots caused by cycling oceanic crust through mantle reservoirs. Nat Geosci 7:366-370

Longaretti G, Rocchi S (1990) Il magmatismo dell'avampaese Ibleo (Sicilia orientale) tra il Trias e il Quaternario: dati stratigrafici e di sottosuolo. Mem Soc Geol It 45:911-925

Lucassen F, Franz G, Romer RL, Pudlo D, Dulski P (2008) Nd, Pb, and $\mathrm{Sr}$ isotope composition of Late Mesozoic to Quaternary intra-plate magmatism in NE Africa (Sudan, Egypt): high- $\mu$ signatures from the mantle lithosphere. Contrib Mineral Petrol 156:765-784

Lustrino M, Anderson DL (2015) The isotopic mantle printer. Basic mantle plume geochemistry for seismologists and geodynamicists. In: Fouger GR, Lustrino M, King S (eds) The interdisciplinary Earth. A volume in honor of Don L. Anderson. Geological Society of America, Special Paper SPE514 (in press)

Lustrino M, Sharkov E (2006) Neogene volcanic activity of western Syria and its relationship with Arabian plate kinematics. J Geodyn 42:115-139

Lustrino M, Wilson M (2007) The circum-Mediterranean anorogenic Cenozoic igneous province. Earth Sci Rev 81:1-65

Lustrino M, Duggen S, Rosenberg CL (2011) The Central-Western Mediterranean: anomalous igneous activity in an anomalous collisional tectonic setting. Earth Sci Rev 104:1-40 
Lyubetskaya T, Korenaga J (2007) Chemical composition of Earth's primitive mantle and its variance: method and results. J Geophys Res. doi:10.1029/2005JB004223

Maniscalco R, De Guidi G, Pedley M, Sturiale G, Grasso M (2010) Geological map of the Corvillo and Mandre basins (Caltanissetta Basin, Central Sicily): explanatory notes. Soc Geol It 129:316-326

Martin-Rojas I, Somma R, Delgado F, Estévez A, Iannace A, Perrone V, Zamparelli V (2009) Triassic continental rifting of Pangea: direct evidence from the Alpujarride carbonates, Betic cordillera, SE Spain. J Geol Soc 166:447-458

Marzoli A, Renne PR, Piccirillo EM, Ernesto M, Bellieni G, De Min A (1999) Extensive 200-million-year-old continental flood basalts of the Central Atlantic Magmatic Province. Science 284:616-618

Marzoli A, Jourdan F, Puffer JH, Cuppone T, Tanner LH, Weems RE, Bertrand H, Cirilli S, Bellieni G, De Min A (2011) Timing and duration of the Central Atlantic magmatic province in the Newark and Culpeper basins, eastern USA. Lithos 122:175-188

Maury RC, Lapierre H, Bosch D, Marcoux J, Krystyn L, Cotten J, Bussy F, Brunet P, Senebier F (2008) The alkaline intraplate volcanism of the Antalya nappes (Turkey): a late Triassic remnant of the Neotethys. Bull Soc Geol Fr 179:397-410

Monjoie P, Bussy F, Lapierre H, Pfeifer HR (2005) Modeling of in situ crystallization processes in the Permian mafic layered intrusion of Mont Collon (Dent Blanche nappe, western Alps). Lithos 83:317-346

Morimoto N (1988) Nomenclature of pyroxenes. Mineral Mag $52: 535-550$

Nägler TF, Kramers JD (1998) Nd isotopic evolution of the upper mantle during the Precambrian: models, data and the uncertainty of both. Precambrian Res 91:233-252

Nakamura N (1974) Determination of REE, Ba, Fe, Mg, Na and K in carbonaceous and ordinary chondrites. Geochim Cosmochim Acta 38:757-775

Obst K, Solyom Z, Johansson L (2004) Permo-Carboniferous extension-related magmatism at the SW margin of the Fennoscandian Shield. In: Wilson M, Neumann ER, Timmerman MJ, Heeremans M, Larsen BT (eds) Permo-Carboniferous magmatism and rifting in Europe. Geological Society, London, Special Publications 223, pp 259-288

Orejana D, Villaseca C, Billstrom K, Paterson BA (2008) Petrogenesis of Permian alkaline lamprophyres and diabases from the Spanish Central System and their geodynamic context within western Europe. Contrib Mineral Petrol 156:477-500

Papike JJ, Cameron KL, Baldwin K (1974) Amphiboles and pyroxenes: characterization of other than quadrilateral components and estimates of ferric iron from microprobe data. Geol Soc Amer Abstr Progr 6:1053-1054

Pearce JA (1982) Trace elements characteristics of lavas from destructive plate boundaries. In: Thorpe RS (ed) Andesites: orogenic andesites and related rocks. Wiley, New York, pp 525-548

Pearce JA (1996) A users guide to basalt discrimination diagrams.In: Wyman DA (ed) Trace element geochemistry of volcanic rocks: applications for massive sulphide exploration. Geological Association of Canada, Short Course Notes 12, pp 79-113

Pe-Piper G (1998) The nature of Triassic extension-related magmatism in Greece: evidence from $\mathrm{Nd}$ and $\mathrm{Pb}$ isotope geochemistry. Geol Mag 135:331-348

Pe-Piper G, Piper DJW (2002) The igneous rocks of Greece. The anatomy of an orogen. Gebruder Borntraeger, Berlin

Pilet S (2015) Generation of low-silica alkaline lavas: petrological constraints, models and thermal implications. In: Foulger GR, Lustrino M, King S (eds) The interdisciplinary Earth. A volume in honor of Don L. Anderson. Geological Society of America, Special Paper SPE514 (in press)
Pilet S, Baker MB, Müntener O, Stolper EM (2011) Monte Carlo simulations of metasomatic enrichment in the lithosphere and implications for the source of alkaline basalts. J Petrol 52:1415-1442

Pomonis P, Tsikouras B, Hatzipanagiotou K (2004) Comparative geochemical study of the Triassic trachyandesites of Glykomilia and alkali basalts from the Koziakas ophiolite mélange (W Thessaly): implications for their origin. Bull Geol Soc Greece 36:587-596

Punturo R, Scribano V (1997) Preliminary geochemical and petrological data on megacrystic pyroxenite and websterite xenoliths from Valle Guffari (Hyblean Plateau, Sicily). Mineral Petrogr Acta 40:95-116

Punturo R, Sturiale G, Vaccaro C, Cirrincione R, Mustica A (2013) Integrated geological and petrographic study supporting the interpretation of ancient artefacts: the case history of Palagonia area (SE Sicily). Ital J Geosc 132:263-273

Romano V, Cirrincione R, Fiannacca P, Lustrino M, Tranchina A (2011) Late-Hercynian post-collisional dyke magmatism in central Calabria (Serre Massif, southern Italy). Period Mineral 80:489-515

Rudnick RL, Fountain DM (1995) Nature and composition of the continental crust: a lower crustal perspective. Rev Geophys 33:267-309

Sanz T, Lago M, Gil A, Galé C, Ramajo J, Ubide T, Pocoví A, Tierz P, Larrea P (2013) The Upper Triassic alkaline magmatism in the NW Iberian Chain (Spain). J Iber Geol 39:203-222

Sayit K, Göncüoğlu MC (2009) Geochemistry of mafic rocks of the Karakaya complex, Turkey: evidence for plume-involvement in the Palaeotethyan extensional regime during the Middle and Late Triassic. Int J Earth Sci 98:367-385

Sayit K, Göncüoğlu MC, Furman T (2010) Petrological reconstruction of Triassic seamounts/oceanic islands within the Palaeotethys: geochemical implications from the Karakaya subduction/accretion Complex, Northern Turkey. Lithos 119:501-511

Sloman LE (1989) Triassic shoshonites from the Dolomites, northern Italy: alkaline arc rocks in a strike-slip setting. J Geophys Res 94:4655-4666

Slovenec D, Lugović B, Meyer HP, Šiftar GG (2011) A tectono-magmatic correlation of basaltic rocks from Ophiolite mélanges at the north-eastern tip of the Sava-Vardar suture zone, northern Croatia, constrained by geochemistry and petrology. Ofioliti 36:77-100

Stampfli GM, Borel GD (2002) A plate tectonic model for the Paleozoic and Mesozoic constrained by dynamic plate boundaries and restored synthetic oceanic isochrons. Earth Planet Sci Lett 196:17-33

Stampfli GM, Hochard C, Vérard C, Wilhem C, vonRaumer J (2013) The formation of Pangea. Tectonophysics 593:1-19

Stracke A (2012) Earth's heterogeneous mantle: a product of convection-driven interaction between crust and mantle. Chem Geol 330-331:274-299

Sun SS, McDonough WF (1989) Chemical and isotopic systematics of oceanic basalts: implications for mantle composition and processes. In: Saunders AD, Norry MJ (eds) Magmatism in ocean basins. Geological Society, London, Special Publications 42, pp 313-345

Tortorici L, Monaco C, Mazzoli S, Bianca M (2001) Timing and modes of deformation in the Western Sicilian thrust system, Southern Italy. J Petrol Geol 24:191-211

Traversa G, Ronca S, Del Moro A, Pasquali C, Buraglini N, Barabino $G$ (2003) Late to post-Hercynian dyke activity in the Sardinia-Corsica Domain: a transition from orogenic calcalkaline to anorogenic alkaline magmatism. Boll Soc Geol It Spec 2:131-152

Vaccaro C, Atzori P, Del Moro A, Oddone M, Traversa G, Villa IM (1991) Geochronology and $\mathrm{Sr}$ isotope geochemistry of 
late-Hercynian dykes from Sardinia. Schweiz Miner Petrog 71:221-230

Villa IM, Ruggieri G, Puxeddu M, Bertini G (2006) Geochronology and isotope transport systematics in a subsurface granite from the Larderello-Travale geothermal system (Italy). J Volcanol Geotherm Res 152:20-50

Villaseca C, Orejana D, Pin C, López García JA, Andonaegui P (2004) Le magmatisme basique Hercynien et post-Hercynien du Système central Espagnol: essai de caractérisation des sources mantelliques. CR Geosci 336:877-888

Wilson M, Patterson R (2001) Intraplate magmatism related to shortwavelength convective instabilities in the upper mantle: evidence from the Tertiary-Quaternary volcanic province of western and central Europe. In: Ernst R E, Buchan KL (eds) Mantle plumes: their identification through time. Geological Society of America Special Papers 352, pp 37-58

Winchester JA, Floyd PA (1977) Geochemical discrimination of different magma series and their differentiation products using immobile elements. Chem Geol 20:325-343

Zanetti A, Mazzucchelli M, Sinigoi S, Giovanardi T, Peressini G, Fanning M (2013) SHRIMP U-Pb Zircon Triassic intrusion age of the Finero mafic complex (Ivrea-Verbano zone, Western Alps) and its geodynamic implications. J Petrol 54:2235-2265

Ziegler PA, Cavazza W, Robertson AHF, Crasquin-Soleau S (2001) Peritethyan Rift/Wrench Basins and Passive Margins. Mémoires du Muséum National d'Histoire Naturelle, Paris 